\title{
A FRAMEWORK FOR SATISFYING CORPORATE DIREGTORS' RESPONSIBILITIES UNDER STATE NONSHAREHOLDER CONSTITUENCY STATUTES: THE USE OF EXPLICIT CONTRACTS
}

\author{
Alexander C. Gavis $\dagger$
}

Few trends could so thoroughly undermine the very foundations of our free society as the acceptance by corporate officials of a social responsibility other than to make as much money for their stockholders as possible. This is a fundamentally subversive doctrine.

- Milton Friedman ${ }^{1}$

\section{INTRODUCTION}

This "subversive doctrine" to which Friedman refers has been adopted and codified by a number of states in the form of nonshareholder constituency statutes. These statutes have expanded the criteria that corporate directors may consider when reaching decisions on behalf of the corporation and have often been adopted along with legislation which attempts to regulate hostile tender offers. ${ }^{2}$

In Pennsylvania, for example, the board of directors or committees of the board may, in determining the best interests of the corporation, "consider the effects of any action [or decision] upon

† B.A. 1986, Swarthmore College; J.D. Candidate 1991, University of Pennsylvania. I would like to dedicate this Comment to my parents and to thank Professor Michael L. Wachter for his suggestions on earlier drafts.

1 M. Friedman, Capitalism and Freedom 133 (1982).

2 A "tender offer" has been defined as:

[A]n offer to stockholders of a publicly owned corporation to exchange their shares for cash or securities at a price above the quoted market price. ... [A cash tender offer] is an offer to an individual shareholder to purchase that person's shares at a price well above the market price, but which is open for a limited time only. Stock being easily replaceable by other stock, the shareholders ordinarily will accept the offer.... [T]ender offers entail certain costs to bidders. They are riskier than the negotiated purchase of a company because surprises often await the bidder. . . . $[T]$ he hostile bidder flies blind, without an opportunity to learn about the target from the inside.

L. Solomon, D. Schwartz \& J. Bauman, Corporations: Law and Policy 1052 (2d ed. 1988). 
employees, upon suppliers and customers of the corporation, and upon communities in which offices or other establishments of the corporation are located ...."3 Similar to antitakeover statutes, these provisions allow corporate directors to consider additional factors when responding to hostile takeovers. The explicit purpose of the statutes, however, appears to be the general protection of nonshareholder constituencies ("stakeholders") who have "contractual" or economic relationships with corporations.

Furthermore, the statutes chip away at the common-law fiduciary duty model of corporate governance ${ }^{5}$ by allowing directors and officers of corporations to weigh stakeholders' interests when making major corporate decisions. The inherent "softness" of the wording of the statutes creates a significant problem, however, as many fail to name specific constituencies, and the ones that are specific do not indicate what types of considerations or measures would fulfill directors' responsibilities. ${ }^{6}$

Stakeholders, nevertheless, are often affected negatively by directors' decisions involving corporate restructurings, ${ }^{7}$ mergers,

342 Pa. Cons. Stat. Ann. $\S 8363$ (Purdon Supp. 1989). As of this writing, Pennsylvania's legislature is in the process of considering what might amount to be the nation's most rigorous antitakeover law. In addition to deterring corporate raiders from running up target corporations' stock prices, the proposed bill allows corporate directors to consider and weigh a broad variety of factors when making decisions. The bill also includes a provision which requires anyone acquiring a Pennsylvania corporation to honor all existing labor contracts. The bill was passed by the Pennsylvania Senate and is under consideration in the House. The relevant part of the fiduciary duty provision in the Senate bill states that directors may consider the "effect of any action upon any or all groups affected by such action, including shareholders, employees, suppliers, customers and creditors of the corporation and upon communities in which offices or other establishments of the corporation are located." In addition, "the board of directors . . . shall not be required ... to regard any corporate interest or the interest of any particular group affected by such action as a dominant or controlling interest or factor." S. 1310, 1989 Sess., §511(b). For a closer examination of existing nonshareholder constituency statutes, see infra notes 51-60 and accompanying text.

4 See infra notes 48 \& 49 and accompanying text.

5 This fiduciary duty of directors in managing a corporation is usually divided between a duty of care and duty of loyalty to the corporation and its shareholders. See L. Solomon, D. Schwartz \&: J. Bauman, supra note 2, at 591.

6 See infra notes 51-60 and accompanying text.

7 A restructuring usually involves a corporation that has been the subject of a tender offer. In response to a tender offer by a third party, the corporation "offers its shareholders a package of debt or preferred stock and cash having a higher value than the tender offer in exchange for a significantly reduced equity position." $L$. Solomon, D. Schwartz \& J. Bauman, supra note 2, at 1131. Restructuring plans often call for sales of whole divisions or some assets of the corporation in order to service new debt. Id. Between January 1984 and mid-July 1985, 398 of the 850 largest North American corforations underwent restructurings. See Coffee, 
acquisitions, and liquidations. ${ }^{8}$ These major corporate decisions may impair investments that stakeholders have made in corporations that have not been fully accounted for or protected through explicit contracts. ${ }^{9}$ In addition, stakeholders may not possess the means necessary to bargain with directors or officers in order to protect themselves against corporate decisions that may adversely affect their investments and welfare. ${ }^{10}$

Employees constitute perhaps the most significant stakeholder group. They are affected directly by practically all major corporate decisions, particularly takeovers. Effects upon employees ripple out to surrounding communities, which possess another stakeholder interest. ${ }^{11}$ For example, corporate restructurings that respond to hostile takeover attempts often involve layoffs or employee terminations. ${ }^{12}$ Employees may have invested a significant amount of "capital" in the corporation. Factors adding to employees' investment in the corporation include: years of service, job education, community contact, quality of life, and other nonpecuniary elements. ${ }^{13}$ This building or accumulating of "human capital"14 in the workplace may not be reciprocated with contractual protection against adverse

Shareholders Versus Managers: The Strain in the Corporate Web, 85 Mich. L. REv. 1, 6 (1986).

8 Mergers, acquisitions, and liquidations may be a result of, or response to, hostile tender offers. See Chairman of the Subcomm. on Telecommunications, Consumer Protection, and Finance of the House Comm. ON ENERgy and Commerce, 99th Cong., 2d Sess., Report: Corporate Takeovers: Public Policy Implications For the Economy and Corporate Governance (Comm. Print 1987), reprinted in L. Solomon, D. Schwartz \& J. Bauman, supra note 2, at 1149, 1162-64 [hereinafter Corporate Takeovers: Public Policy Implications].

9 See Coffee, supra note 7, at 108.

$10 \mathrm{See}$ id. ("Managers and .. . other constituencies share the common circumstances of a nondiversifiable investment in the corporation that makes them risk averse.").

11 Employee layoffs by corporations impact upon local communities by reducing the demand for goods, services, and housing. Increased local unemployment rates may effect local communities' ability to provide social and educational services as a result of reductions in tax revenues. See Corporate Takeovers: Public Policy IMPLICATIONS, supra note 8, at 1162.

12 See id. at 1163 (" $[\mathrm{I}] \mathrm{t}$ is clear that the recent wave of corporate restructuringscharacterized by the increased use of debt to repurchase common stock and boost share prices-has prompted employee layoffs and other cost cutting measures. . . . [I]t is ... a response to the need to boost common stock prices to thwart corporate raiders.").

13 See Raday, Individual and Collective Dismissal-A Job Security Dichotomy, 10 ComP. LAB. L.J. 121, 150 (1989); Singer, The Reliance Interest in Property, 40 STAN. L. Rev. 611, 717-20 (1988).

14 See Raday, supra note 13, at 152-55. See generally G. Becker, Human Caprtal (2d ed. 1975) (discussing the theoretical and empirical bases of human capital). 
events. Individual employees usually do not have the means to protect themselves from either unforeseeable, or even foreseeable, risks of wholesale job loss or loss of human capital investments in corporations. ${ }^{15}$ Compared with shareholders, employees may have less of an ability to withdraw from the corporation and may ultimately hold a larger stake in its future. ${ }^{16}$ Furthermore, unions have not been able to protect workers effectively from collective terminations and the risks of loss as a result of major corporate decisions. ${ }^{17}$

If nonshareholder constituency statutes are thought of as legislative attempts to create entitlements for parties outside the standard shareholder-manager (owner-agent) relationship, ${ }^{18}$ they may indeed represent a form of wealth sharing or redistribution, encouraging those who benefit from major corporate decisions (shareholders) to compensate those who lose as a result of them (those who have a stake, but no ownership). ${ }^{19}$ The statutes, therefore, may provide a coherent framework in which directors might address the concerns of employee stakeholders. Although it might be impossible or impractical for state legislatures to decide how employees' interests should be protected from the risks of takeovers or other major corporate decisions such as plant closings, ${ }^{20}$ it may be feasible for directors to provide adequate protection.

Directors may be able to use standard corporate contracts in order to provide protection for employees. In fact, a series of contracts have already been developed which might assist in compensating workers for increased risk sustained as a result of takeovers,

15 See Raday, supra note 13, at 128.

16 See Summers, Codetermination in the United States: A Projection of Problems and Potentials, 4 J. Comp. Corp. L. 8E SEc. Reg. 155, 170 (1982); see, e.g., Passell, In Takeovers, Play's the Thing, N.Y. Times, Dec. 6, 1989, at D2, col. 1 (reviewing a new play, Other People's Money, which tracks the emotional trauma of a hostile acquisition on a small company and its employees); Baker, Human Factor Often Ignored; Mergers Create Big Firms, Nightmares for E'mployees, L.A. Times, Oct. 2, 1989, at 1, col. 5 (interviewing employees who face an impending acquisition and outlining the "human" and family-related cosrs experienced by these workers, especially their inability to move to other jobs in other parts of the country).

17 See Raday, supra note 13, at 128.

18 See Coffee, The Uncertain Case for Takeover Reform: An Essay on Stockholders, Stakeholders and Bust-Ups, 1988 Wis. L. REv. 435, 447-51.

19 See, e.g., id. at 448 ("Even if there is no net social loss, any wealth transfer here is probably in an anti-egalitarian direction, because employees are losing as shareholders gain."); Coffee, supra note 7, at 12 ("[P]redictably, there are affected bystanders [to bust-up, hostile takeovers]-most notably, managers and employees, but also creditors and ultimately the state as well-who will change their behavior as the significance of the takeover's impact grows on them.").

20 See Coffee, supra note 7, at 108. 
restructurings, or other major corporate decisions: successorship clauses, ${ }^{21}$ "silver" or "tin" parachute agreements, ${ }^{22}$ and employee stock ownership plans. ${ }^{23}$ First, the incorporation of successorship clauses into collective bargaining agreements may help surmount some of the risks associated with collective (unionized) employee terminations. Second, directors might offer silver or tin parachute agreements, fashioned after currently used golden parachute agreements, which would help to provide non-unionized employees with direct or individual compensation for added risks from takeovers. Finally, directors might adopt employee stock ownership plans in order to provide added compensation and assist in the acquisition of stock by workers.

Part I of this Comment examines the hostile takeover environment and the increasing use of antitakeover legislation by the states to protect employees' and other stakeholders' interests. Part II takes a closer look at nonshareholder constituency statutes and the caselaw supporting consideration of stakeholders' interests. Part III presents a contractual view of corporations and concludes that many interests of employees are often not captured through typical contracting processes. Part IV presents the successorship clause, silver and tin parachute agreements, and employee stock ownership plan as explicit contractual methods which directors might use in order to account for employees' interests under nonshareholder constituency statutes and thereby satisfy their duties. Part $\mathrm{V}$ briefly examines a potential criticism of the use of these contracts: the problem of managerial entrenchment.

\section{The Hostile Takeover Environment: Winners, Losers \& REgULATION}

Before the mid-1980s, the takeover landscape consisted mainly of larger corporations digesting smaller firms for synergistic gains, through neutral or friendly tender offers. ${ }^{24}$ Subsequently, a new breed of entrepreneur, including "corporate raiders" and leveraged buyout firms, emerged and mastered the use of the tender offer. ${ }^{25}$

21 See infra note 126 and accompanying text.

22 See infra note 151 and accompanying text.

23 See infra note 167 and accompanying text.

24 See Coffee, supra note 7, at 2.

25 In addition, investment banks also entered the scene as principal investors and temporary lenders in transactions, no longer acting solely as advisors. See id. at 2-3. Investment banks have volunteered to purchase equity positions in many hostile takeovers and have offered temporary ("bridge loan") acquisition financing. In this 
These "financial entrepreneurs" have generally targeted large conglomerate corporations as potential takeover candidates. ${ }^{26}$ Corporate raiders have been successful in arbitraging the difference between stock and asset values of these conglomerates by initially acquiring control and then partially liquidating the companies in order to pay off acquisition indebtedness. ${ }^{27}$ Two modern developments have facilitated the increased number of corporate takeovers, particularly hostile tender offers: the high-yield, non-investment grade ("junk") bond ${ }^{28}$ and the highly-leveraged, bust-up takeover. ${ }^{29}$

type of financing, investment banks provide short-term acquisition funds to acquiring companies that intend quickly to refinance the debt with permanent capital, funded by bank loans, the sale of bonds or notes, or the sale of the target company's assets. Bridge loans are often used in orider to facilitate hostile tender offers. See Lipton, Corporate Governance in the Age of Fincince Corporatism, 136 U. PA. L. REv. 1, 13-15 (1987); Penn, Raiding Parties: Friends and Fielatives Hitch Their Wagon to Carl Ichan's Star, Wall St. J., Oct. 2, 1985, at 1, col. 6.

26 In past years, conglomerates such as General Foods, Richardson-Vicks, Beatrice, Revlon, SCM, CBS, and Anderson Clayton have been either forced to restructure their operations or were acquired as result of hostile bids for control. Takeover attempts for these giant companies were apparently motivated by the perceived disparity between the target companies' liquidation and stock market values. See Coffee, supra note 7, at: 3-5; see also Splitting Up-The Other Side of Merger Mania, Bus. WK., July 1, 1985, at 50, 50-54 (stating that "[c]onglomerates have taken the lead in jettisoning assets. Their goal is to stay ahead of the raiders and get their businesses in focus. ... Having started squeezing down soon after their heyday in the 1960 s, [conglomerates] are now leaping enthusiastically into the restructuring wave and emerging as different animals").

In 1989 Kolhberg, Kravis \& Raberts Co. completed the largest leveraged buyout transaction in history by acquiring the conglomerate RJR Nabisco for approximately 25 billion dollars. See, e.g., Henry Kravis Turns Buyouts Into Empire Worth Billions; RJR Nabisco Takeover Puts KKR at the Top', Wash. Post, Dec. 4, 1988, at Al, col. 5 ("KKR agreed to pay a record $\$ 25$ billion to acquire RJR Nabisco Inc., the food and tobacco giant. The takeover . . . will require an unprecedent $\$ 22.8$ billion in borrowed money."); RJR Nabisco Suiter Claims $\$ 24.88$ Billion Victory, N.Y. Times, Dec. 1, 1988, at Al, col. 1 (relating the same facts).

27 See Coffee, supra note 7, at 3-5.

28 See L. Solomon, D. Schwartz \& J. Bauman, supra note 2, at 1062 (defining a "junk bond" as a "high yield, sometimes high risk, bond that is rated below investment grade by the bond rating agencies. Junk bonds are not new, but their application to takeovers is relatively recent"). These bonds are usually:

[P]urchased by a consortium of wealthy investors or by institutions who

finance the acquiring company's acquisition of the target, so that the shares may be purchased for cash. The acquiring company then merges with the target company, and by operation of law, the junk bonds issued by the purchaser becomes [sic] the obligations of the target.

Id.; see also R. HAMILTON, Corporations 787 (3d ed. 1986) (similarly defining junk bonds).

29 A bust-up takeover is one that results in the "reconstruction of the target company by a sell-off of substantial assets or whole divisions. Often this is necessitated to pay off part of the debt that was incurred to acquired the target." $L$. 
The threat of hostile tender offers, though, may induce managements of corporations to raise efficiency or facilitate inefficient managements' removal. ${ }^{30}$ Changing technology, regulation, or market conditions may require major restructuring of corporate assets in a particular industry, and current managers may be ineffective in making such changes. If stock prices incorporate all currently available information on corporations and management, ineffective management will be penalized in the marketplace. ${ }^{31}$ According to this theory, takeovers create efficiencies by replacing inefficient or entrenched managers; using debt to motivate organizational efficiency; forcing managers to focus on free cash flow to the firm; creating value through facilitating the exit of excess or duplicate resources; building synergy from combining resources and liquidating redundant parts; and reducing overcapacity by paying out large amounts of excess capital to shareholders. ${ }^{32}$ Taken one step further, some scholars argue that society as a whole will benefit from the shifting of resources from lower to higher value uses. ${ }^{33}$ Shareholders' financial interests are thus thought to be congruent with soci-

Solomon, D. Schwartz \& J. Bauman, supra note 2, at 1060 . The era of junk-bond financed, bust-up takeovers apparently began in 1984, when Drexel Burnham Lambert arranged junk bond financing for Boone Pickens' bid for Gulf Oil Corporation. According to Lipton:

By mid-1985, the flow of junk-financed takeovers had become "an avalanche." ... [W] [Wile bond issues represented only $0.3 \%$ of tender offer financing for the years 1981 through 1984, one study concluded that, in the first half of 1985, junk bonds accounted for $13.6 \%$ of all successful tender offer financing and $24.7 \%$ of hostile tender offer financing.

Lipton, supra note 25, at 11-12. (citations and footnotes omitted).

30 See, e.g., The Battle for Corporate Control, Bus. WK., May 18, 1987, at 102, 103 [hereinafter Battle for Corporate Control] (quoting Richard M. Schlefer, Investment Manager of College Retirement Equities Fund: "We view tender offers as a kind of free, competitive market for management. The best managers will end up running a company.").

31 See Jensen, Takeovers: Their Causes and Consequences, 2 J. ECoN. PErsp. 21, 23-25 (1988); see also Jensen \& Ruback, The Market for Corporate Control: The Scientific Evidence, J. Fin. Econ., Apr. 1983, at 5, 8-9, 29-39 (noting that managerial actions that eliminate potential bidders, such as targeted large-block repurchases or standstill agreements, apparently are costly to shareholders and the marketplace generally); Macey, State Anti-Takeover Legislation and the National Economy, 1988 WIs. L. REv. 467, 472 (concluding that " $[\mathrm{t}]$ he wealth-enhancing view of takeovers is supported by the fact that top managers lose their jobs when their firms are the subject of a successful hostile takeover").

32 See Jensen, supra note 31 , at 23-39.

33 See id. 
ety's general interest in efficiency in production and in the capital markets. ${ }^{34}$

While it has been accepted by most scholars that shareholders of target corporations have been the primary winners in contests for corporate control, ${ }^{35}$ the effects of such contests upon managers, employees, buyers and suppliers, and state and local communities have been disputed.$^{36}$ Restructurings of corporations in response to

34 See Easterbrook \& Fischel, Auctions and Sunk Costs in Tender Offers, 35 STaN. L. Rev. 1, 49 (1982); Easterbrook \&: Fischel, The Proper Role of a Target's Management in Responding to a Tender Offer, 94 HARv. L. Rev. 1161, 1174-80 (1981). See generally Easterbrook \& Fischel, Takeover Bids, Defensive Tactics, and Shareholders' Welfare, 36 Bus. LAw. 1733, 1739-45 (1981) (noting that the "productive economic benefits" to society and shareholders from tender offers cuts against arguments calling for resistance and defensive tactics to takeover attempts).

35 Shareholders of companies caught in the midst of hostile takeovers can expect to realize from 50 to 100 percent appreciation in value of their holdings. See Coffee, Regulating the Market for Corporate Control: A Critical Assessment of the Tender Offer's Role in Corporate Governance, 84 Colum. L. REv. 1145, 1162-63 (1984). Target firm shareholders often realize unprecedented appreciation and liquidity for their investments. One scholar has computed the average premium paid to target firm shareholders in a successful tender offer (based on the market price two months prior to the offer's announcement) to be approximately 49 percent. See id. at $1162 \mathrm{n} .34$ (citing study by Bradley, Interfirm Tender Offers and the Market for Corporate Control, $54 \mathrm{~J}$. Bus. 345 (1980)). Cf. Jarrell \& Bradley, The Economic Effects of Federal and State Regulations of Cash Tender Offers, 23 J.L. \& EcoN. 371, 373 (1980) (estimating that the average cash tender offer premium had risen to almost 73 percent after a wave of state antitakeover statutes; the percentage was calculated from the target's share price $\mathbf{4 0}$ days prior to the tender offer); Jensen \& Ruback, supra note 31, at 7 (finding that stock price gains of targets in successful tender offers averaged 30 percent, and in successful mergers, averaged 20 percent).

Economists have recently attempted to place a dollar value on the overall gains to shareholders from successful tender offers (and corresponding takeover) transactions. Jensen has estimated that in the ten year period between 1976 and 1986 the gains to target firm shareholders from merger and acquisition activity totalled 346 billion dollars (in 1986 dollars). See Jensen, supra note 31, at 21 (using data from M. Grimm, Mergerstat Review (1986) for estimates). Such gains are close to 51 percent of the total cash dividends (in 1986 dollars) paid to investors by the entire corporate sector over the past ten years. See id.

36 See Brown \& Medoff, The Impact of Firm Acquisitions on Labor, in CoRporate Takeovers: Causes and Consequences 9, 9-31 (A. Auerbach ed. 1988); Grundfest Challenges Argument That Takeovers Cause Job Losses, 20 Sec. Reg. \& L. Rep. (BNA) 423 (1988); Jensen, supra note 31, at $2.2-24$.

One scholar has concisely framed the economic aspects of this issue:

Thus the central question is whether the shareholders who are the big winners are enjoying the premiums they do because bidders with better ideas are willing to share the wealth (which is fine), or whether premiums sometimes (or even often) are paid out of savings expected to be generated by the acquirer's reneging on contracts with managers, suppliers, customers, or employees (which may not be fine).

Booth, State Takeover Statutes Revisted, 88 Mich. L. REv. 120, 127 (1989). 
hostile tender offers often involve "major organizational change (such as shifts in corporate strategy) to meet new competition or market conditions, increased use of debt, and a flurry of recontracting with managers, employees, suppliers and customers."37 This type of activity results in the expansion of resources in certain areas and retraction in others, leading to plant closings, ${ }^{38}$ job terminations, early or forced retirement of managers and employees, and reduced compensation. ${ }^{39}$

Perhaps one of the most pressing dilemmas confronting corporate directors and officers is the "identification of the appropriate constituency to serve [when] evaluating a tender offer." 40 The increasing use by officers of corporate defenses ${ }^{41}$ to hostile tender

37 Jensen, supra note 31 , at 22.

38 See Singer, supra note 13, at 614-18.

39 See, e.g., Proxmire, What's Right and Wrong About Hostile Takeovers? 1988 Wis. L. REv. 353, 360 (concluding that hostile takeovers and leveraged buyouts "have led directly to the elimination of jobs" in the economy).

40 Note, Stakeholder Versus Stockholder: The Director's Proper Constituency in a Contest for Corporate Control, 15 WM. MrTchell L. REv. 475, 476 (1989). With these concerns in mind, Hicks B. Waldron, then Chairman of Avon Products Inc., stated:

We have 40,000 employees and 1.3 million representatives around the world. We have a number of suppliers, institutions, customers, communities. None of them have the democratic freedom as shareholders do to buy or sell their shares. They have much deeper and much more important stakes in our company than our shareholders.

Battle for Corporate Control, supra note 30, at 103. This dilemma is a part of a broader and much older debate concerning managers' representation of proper constituencies and corporate social responsibility. See, e.g., Dodd, For Whom Are Corporate Managers Trustees?, 45 HaRv. L. REV. 1145 (1932) (proposing to broaden the scope of managers' role in representing constituencies other than shareholders). But see Berle, For Whom Corporate Managers Are Trustees: A Note, 45 HARv. L. Rev. 1365, 1367 (1932) (objecting to Professor Dodd's broadening of managers' responsibilities).

41 Some prevalent corporate defenses which have been used by corporate directors and managements throughout the 1980 s include: instituting a "pac-man" defense; restricting the voting rights of large stockholders; adopting share purchase rights plans ("poison pills"), enabling rights-holders the opportunity to purchase shares of an acquiror at half-price in the event a target is merged into an acquiring company; paying greenmail to a corporate raider; liquidating a company; instituting "crown jewel" or "lock-up" options in which the target conveys an option to a favored acquiring company for purchase of especially valuable assets or stock; negotiating a "defensive merger" by finding a "white knight" alternative (a less hostile acquiror); negotiating a placement of a large block of stock into the friendly hands of a third party ( $a$ "white squire"); or adopting a "shark repellent" provision in the target company's articles of incorporation or by-laws that is designed to deter a bidder's interest (some examples include: creating staggered board of director's terms, requiring supermajority approval of a merger with a large shareholder, and creating a "fair price" amendment). See R. GiLson, The LAw and Finance of Corporate AcQuisitions 626-75 (1986); L. Solomon, D. SchWartz \& J. Bauman, supra note 2, at 1059-65; Lipton, supra note 25 , at 28-34. 
offers, along with the rising amount of state anti-takeover legislation, has threatened a "fundamental postulate of modern corporation law. ... [that a] corporation exists for the financial benefit of its shareholders [and] management must devote itself to this single purpose with relentless fidelity." 42 Institutional investors have vigorously attacked the adoption and use of corporate defense tactics by managers of large public corporations threatened by hostile bids. These equity holders claim that defensive tactics have restricted the choices of target shareholders and deny opportunities to realize stock appreciation value through takeovers. ${ }^{43}$

It has become increasingly clear that the antitakeover statutes adopted over the years among the states have been designed to protect the existing corporation and its nonshareholder constituencies. ${ }^{44}$ Although state legislatures may have accepted in theory the notion of centrality of shareholders' interests in corporate affairs and

42 Millon, State Takeover Laws: A Rebirth of Corporation Law?, 45 WASH. \& LEE L. Rev. 903, 903 (1988); see, e.g., Law, A Corporation is More than Its Stock, 64 HARv. Bus. Rev. 80, 83 (1986) ("It is undeniable that managers and employees have responsibilities to shareholders. But is it also inconceivable that shareholders have responsibilities to them?").

43 Institutional investors, including pension funds, mutual funds, banks, and insurance companies, own a significant portion of equity of all publicly traded corporations in the United States. See Lipton, supra note 25, at 7. The Council of Institutional Investors, an interest group with more than 50 pension fund members, controlling 200 billion dollars worth of investments, adopted a "Shareholders Bill of Rights" in April 1986, which demanded that shareholder approval be required for a wide range of management actions. See, e.g., Battle for Corporate Control, supra note 30, at 103 (reporting that the Council of Institutional Investors led a proxy fight against antitakeover defense tactics in 40 shareholder meetings in the spring of 1988); Lipton, supra note 25, at 28 (stating that "[t] hese tactics, which restrict the choices of target shareholders and may be undesirable in the abstract, are currently legitimate responses to abusive takeover schemes, such as the highly leveraged, asset-stripping takeover").

44 On this point, Professors Lyman Johnson and David Millon state that the goal of antitakeover laws is "not to maximize share values for target company investors, whether by eliminating coercion or otherwise, and no apology can alter that fact. Instead, their chief purpose is to protect nonshareholders from the disruptive impact of the corporate restructurings that are thought typically to result from hostile takeovers." Johnson \& Millon, Missing the Point About State Takeover Statutes, 87 MrcH. L. REv. 846, 848 (1989); see also Millon, supra note 42, at 904 (stating that "[w]hile state takeover legislation often pays lip service to shareholder welfare, such legislation actually has a different purpose, a purpose fundamentally antithetical to the shareholder primacy norm of present corporation law"). But see Booth, supra note 36 , at 129 (suggesting that there might be hidden benefits to shareholders from control share statutes even though the statutes may support some stakeholders' interests); Booth, The Promise of State Takeover Statutes, 86 Mich. L. REv. 1635, 1681 (1988) (claiming that control share acquisition takeover statutes represent a "remarkably intelligent approach to the problem of fairness in tender offers" and may aid shareholders in realizing value through tender offers). 
may have observed the need to redress the imbalances in the relationship between managers and shareholders, "states also saw a different side of the rampant takeover activity-the social responsibility side-and began to question whether attaining takeover benefits for shareholders was as consistent with other important interests as economic and legal orthodoxy presumed."45

State legislatures perceived that the major benefits of bust-up, hostile takeovers would be primarily enjoyed by residents of many states (i.e., dispersed shareholders), leaving the economic and social costs of the transactions to fall disproportionately within the boundaries of those states having substantial connections to the target companies. They feared the costs of the "closing or moving of corporate headquarters and plants," the loss of employment for in-state workers, the "loss of income, property, and sales tax revenues ... [the] reduction of charitable contributions to dependent nonprofit organizations, and [the losses] to the target [corporation's] web of suppliers, dealers, and customers."46

By 1982, under pressure from local constituencies and corporate managements, thirty-six states enacted antitakeover legislation, often strengthening the disclosure requirements imposed by the Williams Act. ${ }^{47}$ These first-generation statutes have been followed over the years by second- and third-generation statutes ${ }^{48}$ as legislatures responded to successful legal attacks on their constitutionality. ${ }^{49}$

45 Johnson, The Eventual Clash Between Judicial and Legislative Notions of Target Management Conduct, 14 J. CoRP. L. 35, 67 (1988).

46 Id.

47 See L. Solomon, D. Schwartz \& J. Bauman, supra note 2, at 1088.

48 The current state antitakeover laws have been called "second-" and "thirdgeneration" laws. Second-generation laws were drafted by legislatures to avoid the constitutional problems that caused the Supreme Court to invalidate "firstgeneration" laws in Edgar v. MITE Corp., 457 U.S. 624, 643-46 (1982). Thirdgeneration laws were passed in response to the Supreme Court's decision in CTS Corp. v. Dynamics Corp. of America, 481 U.S. 69 (1987). Recently, the Supreme Court refused to hear a challenge to Wisconsin's antitakeover law which requires a bidder who acquires at least 10 percent of a target company's shares either to gain approval of the target's board of directors or to wait three years before completing a merger. It would appear by this decision that the Supreme Court has left the states with substantial authority to regulate hostile tender offers. See Wermiel, Supreme Court Declines to Review Law in Wisconsin Curbing Hostile Takeovers, Wall St. J., Nov. 7, 1989, at B12, col. 5 .

49 In general, antitakeover laws have been categorized as control-share acquisition provisions, fair price provisions, redemption rights statutes, business combination statutes, and nonshareholder constituency provisions. For a discussion of the first four categories and their variations, see Johnson, supra note 45 , at $36 \mathrm{n} .3$, 61-88; Macey, supra note 31, at 468 n.4, 469-71; Romano, The Political Economy of Takeover Statutes, 73 VA. L. REv. 111, 111-21 (1987). 
Much has been written on these antitakeover statutes and it is beyond the scope of this Comment to address the issues raised by them. ${ }^{50}$

\section{ACCOUNTING For StAKEHOLDERs' INTERESTS}

\section{A. Legislative Efforts}

Almost half of all states have adopted statutes which expand the criteria that directors may look to in reaching decisions or exercising their business judgment on behalf of the corporation. ${ }^{51}$ Ohio's stat-

50 See, e.g., Millon, supra note 42, at 903-05 (outlining many of the major corporate law issues raised by the statutes); Romano, supra note 49 , at 120-42 (examining the political motivations behind the statutes).

51 Although the statutes exist in several different forms, all relate to the standard of care in which directors (and officers) must discharge their duties. The statutes might be best characterized as follows: Best Interests Statutes-Statutes in which states permit directors making corporate decisions to consider the long-term as well as the short-term interests of the corporation and its shareholders, including the possibility that these best interests might be served by the continued independence of the corporation. Arizona and Connecticut actually require directors to consider these interests; Specific Constituencies-Statutes in which states permit directors to consider only the imrnediate interests of the shareholders and specific nonshareholder constituencies, including employees, bondholders, suppliers, customers, communities or other groups, and the economy of state and nation; Mixed Statutes-Statutes in which states permit or require consideration of the corporation's best interests (long- and short-term) and permit consideration of specific constituencies. Connecticut requires that directors consider the best interests of the corporation along with the interests of shareholders and nonshareholder constituencies when making decisions relating to a change of control.

See, e.g., ARIz. Rev. Stat. AnN. § 10-1202 (Supp. 1989) (best interests statuterequiring directors to consider the "long-term as well as short-term interests of the corporation and its shareholders"); ConN. Gen. Stat. ANN. § 33-313(e) (West Supp. 1989) (mixed statute requiring directors to consider best interest and constituencies in a change of control); FLA. STAT. ANN. § 607.111(9) (West Supp. 1990) (mixed); IDAHO CODE \$ 30-1702 (Supp. 1989) (mixed); Ill. ANN. STAT. ch.32, para. 8.85 (Smith-Hurd Supp. 1989) (mixed and the statute extends to officers of the corporation); IND. CoDE AnN. § 23-1-35-1(d) (Burns 1989 \& Supp. 1989) (mixed); Ky. Rev. Star. Ann. \$271A.397(4) (Michie/Bobbs-Merrill Supp. 1988) (mixed); ME. Rev. Stat. Ann. tit. 13-A, § 716 (Supp. 1989) (specific constituencies and the statute extends to officers); Minn. Stat. AnN. § 302A.251(5) (West Supp. 1990) (mixed); Mo. AnN. Stat. $\$ 351.347(4)$ (Vernon Supp. 1989) (the statute only relates to a board's consideration of an acquisition proposal and enumerates specific constituencies); NEB. REv. STAT. $\$$ 21-2035(1) (Supp. 1988) (mixed); N.M. STat. ANN. § 53-11-35(D) (Supp. 1989) (mixed); N.Y. Bus. CoRP. LAW $\S 717$ (b) (McKinney Supp. 1990) (mixed statute for directors' decisions including, without limitation, those which relate to a change of control); Ohio Rev. Code ANN. \$ 1701.59(E) (Anderson Supp. 1988) (mixed); 42 PA. Cons. Stat. Ann. \$ 8363(b) (Purdon Supp. 1989) (mixed); Wis. Stat. Ann. $\$ 180.305$ (West Supp. 1989) (rnixed and extends to officers); see also Hanks, Evaluating Recent State Legislation on Director and Officer Liability Limitation and Indemnification, 43 Bus. LAw. 1207, 1246-53 (1988) (appendix) (listing 
ute is representative of the statutes that allow directors to consider the best interests of the corporation and the interests of specific nonshareholder constituencies:

[A] director, in determining what he reasonably believes to be in the best interests of the corporation, shall consider the interests of the corporation's shareholders and, in his discretion, may consider any of the following:

(1) The interests of the corporation's employees, suppliers, creditors, and customers;

(2) The economy of the state and nation;

(3) Community and societal considerations;

(4) The long-term as well as short-term interests of the corporation and its shareholders, including the possibility that these interests may be best served by the continued independence of the corporation. ${ }^{52}$

In all of the states, except Connecticut and Missouri, directors may consider either the best interests of the corporation or stakeholders' interests in connection with any decision submitted to them. Connecticut and Missouri have limited the application of their statutes to acquisition proposals. ${ }^{53}$

Most of the statutes do enumerate specific groups ${ }^{54}$ that direc-

nonshareholder constituency statutes along with corresponding antitakeover statutes).

52 Ohio Rev. Code AnN. § 1701.59(E) (Anderson Supp. 1988).

53 See Conn. Gen. Stat. Ann. § 33-313(e) (West Supp. 1989); Mo. Ann. Stat. $\S 351.347$ (Vernon Supp. 1989).

54 Since antitakeover statutes are designed to prevent "high unemployment and erosion of the State and local economy and tax base," see 1987 N.C. Sess. Laws 124, reprinted in Johnson \& Millon, supra note 44 , at 849 , it is logical to assume that they would be supported by a coalition of local interests, including labor and community groups.

Apparently, this was found not to be the case in Connecticut. One scholar has noted that the state's "second-generation" antitakeover statute was not generally supported by broad coalitions of local interests, including labor and local community groups, but was supported by one particular corporation. See Romano, supra note 49, at 122-23. Professor Roberta Romano claims that:

The spur behind the passage of the Connecticut [second-generation antitakeover] statute was not a broad-based political coalition. Rather, the bill was promoted by a corporation incorporated in Connecticut, the Aetna Life and Casualty Insurance Company ... . which enlisted the support of the most important business association in the state, the Connecticut Business and Industry Association .... .

Id.

On the other hand, Wisconsin's experience in adopting antitakeover laws in 1987 was found to be consistent with a coalition theory in which state labor groups and other non-business interest groups actively supported the legislation. See Davis, 
tors may consider. New York, for example, recently amended its statute $^{55}$ to allow directors to consider the short- and long-term effects that their decisions may have upon the corporation's current employees, retired employees, ${ }^{56}$ customers, creditors, and ability "to provide, as a going concern, goods, services, employment opportunities and employment benefits and otherwise to contribute to the communities in which it cloes business." 57 The groups most frequently listed among all statutes are employees, ${ }^{58}$ suppliers, customers, ${ }^{59}$ and local communities. ${ }^{60}$ None of the statutes, however, provide a coherent framewrork to guide directors in satisfying their duties to these constituencies. Thus, corporate directors are left to determine the correct balances between the best interests of the stockholders, the corporation, and other constituencies. Conflicting interests frequently make this determination inherently difficult: in a

Epilogue: The Role of the Hostile Takeover and the Role of the States, 1988 WIS. L. REv. 491, 496-97. Even though nonshareholder interest groups such as organized labor or municipalities may not be the actual sponsors of antitakeover legislation, they may actively support it once it has been proposed. See Coffee, supra note 18 , at $437 \& \mathrm{n} .8$ (noting the current debate over the nature of the political coalition supporting antitakeover legislation and arguing that the silence of labor groups and communities may actually imply consent).

55 The New York statute entitles corporate directors "[i]n taking action ... to consider, without limitation, (1) both long-term and short-term interests of the corporation and its shareholders and (2) the effects that the corporation's actions may have in the short-term or in the long-term upon [enumerated constituencies]." See N.Y. Bus. CoRP. LAW $\S 717$ (b) (McKinney Supp. 1990) (amending 1989 version of the statute).

56 The statute includes "retired employees and other beneficiaries receiving or entitled to receive retirement, welfare or similar benefits from or pursuant to any plan sponsored, or agreement entered into, by the corporation." Id.

57 Id. In addition to the above noted groups, the statute also allows directors to consider "the prospect for potential growth, development, productivity and profitability of the corporation." Id.

58 Employees are mentioned in all of the mixed and specific constituency statutes and are always the first group to be listed in these statutes. See supra notes 51 \& 52 and accompanying text. See id.

59 Suppliers to and customers of the corporation are often mentioned together.

60 Several of the statutes lirnit consideration of community interests to those areas in which offices or other establishments of the corporation are located or to where the corporation "conducts its business." See, e.g., Mo. AnN. STAT. § 351.347(4) (Vernon Supp. 1989); 42 PA. Cons. Stat. ANN. \& 8363(b) (Purdon Supp. 1989). Other statutes have a broader scope. Kentucky, for example, allows directors to consider the interests of the "economy of the state and nation [and] [c]ommunity and societal considerations.” Ky. REv. Stat. ANn. § 271A.397(4) (Michie/Bobbs-Merrill Supp. 1988). Creditors are often not specifically mentioned in a majority of statutes. See, e.g., Booth, supra note 36, at 126 ("Could it be that the only stakeholders who have been targeted in this campaign to project responsibility are those who have relatively little bargaining power and are being exploited by the stake itself?"). 
typical takeover situation, the best interests of nonshareholders such as employee groups may be the continued independence of the corporation, while the best interests of stockholders may be a sale or liquidation. ${ }^{61}$

Since the best interests of stakeholders have not been defined per se, ${ }^{62}$ these statutes may represent an avenue for directors to compensate stakeholders for losses incurred through decisions supporting shareholder wealth maximization. It may indeed be possible for directors to follow a path of shareholder wealth maximization if entitlements have already been garnered and explicitly contracted for stakeholders, ex ante to takeover situations. This point will be further developed in Part III.

\section{B. American Law Institute's Principles of Corporate Governance}

In its most recent tentative draft on corporate governance principles, the American Law Institute ("ALI") has attempted to navigate a narrow course between conflicting interests of shareholders and stakeholders. ${ }^{63}$ Ultimately the draft supports the primacy of shareholder interests. The ALI would allow directors to take actions that have the "foreseeable effect of blocking an unsolicited tender offer" unless the action materially disfavors the long-term interests of shareholders. ${ }^{64}$ In order to determine whether such an action

61 Outside the legislative arena, several corporations have adopted charter amendments which allow directors to consider stakeholders' interests when making decisions related to a change of control. See Hanks, supra note 51, at 1228 (noting that these charter amendments were the origin of non-stockholder constituency statutes); see also Lipton, supra note 25, at 41 \& n.188 ("For example, Control Data Corp. and McDonald's have recently amended their charters in this fashion."). The provisions allow, and in some cases require, that directors consider nonmonetary factors when deciding upon a hostile tender offer, exchange offer, or business combination. These nonmonetary factors often include the social and economic effects of an acquisition on the target's employees, suppliers, customers, and others. Unlike the statutory context, directors in these corporations have been given a basis for decisionmaking that has been approved by the shareholders. This effectively mitigates against any conflict that directors might encounter when making major decisions because the shareholders have already approved a charter amendment explicitly allowing the directors to consider "other interests." See 1 Shark Repellants and Golden Parachutes: A Handbook for the Practitioner 194-211 (R. Winter, M. Stumpf \& G. Hawkins eds. 1983) [hereinafter SHark REpellants] (reprinting the provisions of Nortek, Inc., Control Data Corp., Central Bancshares of the South, Inc., McDonald's Corp., and Anchor Hocking Corp.).

62 See Hanks, supra note 51, at 1229.

63 See Lipton, supra note 25, at 47-52.

64 See AlI, Principles of Corporate Governance: Analysis and Recommendations $§ 6.02$ (a) (Discussion Draft No. 2, April 20, 1989). 
"would materially disfavor the [shareholders'] long-term interests," the board of directors may consider, ${ }^{65}$ among other factors, ${ }^{66}$ "the impact on groups other than shareholders with respect to which the corporation has a legitimate concern ...."67

In its comments, the ALI states that "[i]n looking to the longterm interests of the shareholders, directors may consider the fact that the long-term well-being of the shareholders requires stable relationships with suppliers and customers and a cooperative relationship with the communities in which the corporation does business." 68 However, it is only when "competing courses of action have comparable impact on shareholders [that] the board of directors may consider in some degree other groups with respect to which the corporation has a legitimate concern." 69 Thus, in comparison to the states' nonshareholder constituency statutes, the ALI's draft preserves little room for the consideration of nonshareholder groups in directors' decisions. ${ }^{70}$

\section{Judicial Efforts}

Although case law interpreting nonshareholder constituency statutes appears to be nonexistent, ${ }^{71}$ in the past courts have recog-

65 The ALI additionally states that the board of directors "should consider the nature, timing, and adequacy of the offer, the risk of nonconsummation of the offer, and questions of legality ...." I Id.

66 Other specified factors include: "the past actions of the bidder and its affiliates in other takeover contexts ...." Id.

67 Id.; see also id. at $\$ 6.02$ (b) "'In reviewing an action of the board of directors ... the standard of review should be whether the board of directors reasonably concluded that their action would not materially disfavor the long-term interests of the shareholders.").

$68 I d$. at $\S 6.02$ comment $c(2)$.

69 Id. at comment a.

70 In fact, the ALI draft promotes the interests of shareholders in a similar fashion to that found in recent Delaware case law. See, e.g., Revlon, Inc. v. MacAndrews \& Forbes Holdings, Inc., 506 A.2d 173, 176 (Del. 1986) ("[W]hile concern for various corporate constituencies is proper when addressing a takeover threat, that principle is limited by the requirement that there be some rationally related benefit accruing to the stockholders."); Goldman \& Walsh, Delaware Courts Revisit Landmark Revlon, Nat'l L.J., Sept. 25, 1989, at S4, col. 1 (discussing the Unocal and Reulon decisions).

71 This may, in part, be a product of corporate activity, or lack thereof, in the states that have adopted the provisions. In addition, New York, a state with a high amount of takeover activity, originally adopted a "watered down" nonshareholder constituency statute which allowed directors to consider the "long-term interests" of the corporation. Only very recently, New York amended its statute to enumerate specific stakeholder groups. See subra notes 51 \& 55-57 and accompanying text. See generally Davis, Discretion of Corporats Management to Do Good at the Expense of Shareholder 
nized that directors may consider stakeholders' interests. Although Delaware does not have a nonshareholder constituency statute on its books, its courts have considered the issue in a series of cases. In Unocal Corp. v. Mesa Petroleum Co., ${ }^{72}$ the Delaware Supreme Court, in upholding a target's self-tender that excluded a raider from participation, stated that a target's board of directors may consider "the impact [of a hostile bid] on 'constituencies' other than shareholders (i.e., creditors, customers, employees, and perhaps even the community generally) ...."73

One year later, however, the Delaware Supreme Court held in Revlon, Inc. v. MacAndrews $\mathcal{E}$ Forbes Holdings, Inc. ${ }^{74}$ that a target's board of directors may not consider the interests of noteholders after a decision has been made to sell the company. Once a sale of the company had become inevitable, the directors' duty changed from "defenders of the corporate bastion to auctioneers charged with getting the best price for the stockholders . . . " "75 The court did recognize that "[a] board may have regard for various constituencies in discharging its responsibilities, provided there are rationally related benefits accruing to the stockholders."76 Redistribution of gains would not be a benefit accruing to stockholders. Thus, the Delaware Supreme Court has reaffirmed that the primary objective of directors conducting an auction must be to obtain the highest price for shareholders and that consideration of the impact of a takeover on corporate constituencies may be examined, "provided that it bears some reasonable relationship to ... basic stockholder interests at stake ...."77 Examining the Unocal and Revlon decisions together, it appears that directors may consider the interests of nonshareholders before an auction has begun, but any decision related to consid-

Gain-A Survey of, and Commentary on, the U.S. Corporate Law, 13 CAN.-U.S. L.J. 7, 20-48 (1988) (outlining various sources for managements' discretion to consider nonshareholder interests, including the business judgment rule and enlightened selfinterest doctrine).

72493 A.2d 946 (Del. 1985).

$73 \mathrm{Id}$. at 955.

74506 A.2d 173 (Del. 1986).

$75 \mathrm{Id}$. at 182 ("[C]oncern for non-stockholder interests is inappropriate when an auction among active bidders is in progress ... ."); see also Sussman \& Sussman, Litigation Intensifies on Duties of Target's Directors, Legal Times, May 26, 1986, at 10, col. 1 ("The broader holding of the case . . . was that Revlon Inc.'s directors breached their fiduciary duties when they granted an asset lock-up to a white knight, Forstmann Little \& Co., which stymied a raid by Pantry Pride Enterprises Inc.").

76 Revlon, $506 \mathrm{~A} .2 \mathrm{~d}$ at 182 (citing Unocal, $493 \mathrm{~A} .2 \mathrm{~d}$ at 955 ).

77 Mills Acquisition Co. v. Macmillan, Inc., 559 A.2d 1261, 1282 n.29 (Del. 1988); see, e.g., Goldman \& Walsh, Delaware Courts Revisit Landmark Revlon, supra note 70 , at $\$ 4$, col. 1 (outlining the future impact of the MacMillan decision). 
eration of nonshareholders must result in some benefit to stockholders, for it is to them that the target's board of directors owes a primary duty of loyalty. ${ }^{78}$

A handful of decisions in other states have more strongly defended the consideration of nonshareholder interests by directors. ${ }^{79}$ Herald Co. v. Seawell ${ }^{80}$ may be the most frequently cited source of authority for support of directors' consideration of takeover effects on stakeholders. ${ }^{81}$ The Tenth Circuit held that the Denver Post legitimately used defensive maneuvers against a hostile bid by Samuel I. Newhouse, owner of one of the nation's largest newspaper chains and an owner with a history of labor difficulties. ${ }^{82}$ In

78 See Mills Acquisition Co., 559 A.2d at 1280, 1282 n.29.

79 See, e.g., Baron v. Strawbridge \& Clothier, 646 F. Supp. 690, 697 (E.D. Pa. 1986) (holding that "[i]t was proper for the company to consider the effects the Berry tender offer would have, if successful, on the Company's employees, customers and community. The Company concluded these effects would be detrimental to its success.") (footnote omitted); Enterra Corp. v. SGS Assoc., 600 F. Supp. 678, 689 (E.D. Pa. 1985) (asserting that management might consider the takeover concerns of suppliers, customers, lenders, and the stability of the company when considering takeover bids). In upholding defensive measures used by Union Carbide to avoid a bust-up bid by GAF Corp., Judge: Pollack of the Southern District of New York stated:

A corporation with a perceived threat of dismemberment of large divisions of the enterprise, employing thousands of employees, owes substantial regard for their pension benefits, and in the case of loyal management, severance benefits. . . . The exercise of independent, honest business judgment . . . is the traditional and appropriate way to deal fairly and even-handedly with both the protection of investors, on the one hand, and the legitimate concerns and interests of employees and management of a corporation who service the interests of investors, on the other.

GAF Corp. v. Union Carbide Corp., 624 F. Supp. 1016, 1019-20 (S.D.N.Y. 1985).

80472 F.2d 1081 (10th Cir. 1972).

81 See Sussman \& Sussman, Takeover Cases Eye Non-Stockholder Interests, Legal Times, Apr. 28, 1986, at 24, col. 2.

82 The Denver Post is a large newspaper with a long tradition of local ownership through the Bonfils family. In May 1960, Samuel I. Newhouse purchased 18 percent of the outstanding shares of the Post with an intent to acquire the entire newspaper. On July 7, 1960, the Post purchased about 21 percent of its outstanding stock held by the Denver U.S. National Bank as trustee for the Children's Hospital Association. For several years before the purchase the board of directors of the Post had considered establishing an employee stock ownership plan. After the purchase of the Children's Hospital shares the board implemented such a plan and transferred 5,000 treasury shares to the plan's trust. A member of the Bonfils family also donated a number of shares to the trust. As of December 1969, 415 of the eligible 1159 employees had purchased shares from the trust. More than eight years after the purchase of the Children's Hospital stock by the Post, Newhouse brought a derivative action on behalf of the Post. The: suit was against the Post's officers and directors for alleged misconduct, breach of trust, and misuse of assets. Newhouse claimed that the board and trustee of the employ'ee stock trust had conspired to acquire a sufficient 
response to the Post's concerns for its nonshareholder constituencies, the court stated:

We are fully cognizant of the well established corporate rule of law which places corporate officers and directors in the position of fiduciaries for the stockholders.... In this case we have a corporation engaged chiefly in the publication of a large metropolitan newspaper, whose obligation and duty is something more than the making of corporate profits. Its obligation is threefold: to the stockholders, ... employees, and . . public. $^{83}$

First amendment and free-press concerns aside, ${ }^{84}$ it is important to note that the court found that the Post's establishment of the "Employees Stock Trust Plan" was legitimate, legal, and "clearly within the power and authority granted by [state] statute to the corporation"85 and was not malevolently motivated. ${ }^{86}$ The Post's use of the plan was to "benefit the public, the corporation and the employees."87

The directors of the Post desired to develop a plan which would provide an opportunity for its employees to participate in stock ownership. ${ }^{88}$ In fact, the Post's directors personally investigated other employee stock ownership plans at other newspapers. Apparently, the directors sincerely believed that employee stock ownership would promote a better employee-employer relationship. The directors also believed that employee stock ownership would eventually lock control of the corporation in the employees and eliminate outsider control of stock. ${ }^{89}$ The court held that since the plan was approved by a substantial majority of stockholders it would not impose its business judgment on the directors. ${ }^{90}$ In addition, the motives for establishing the plan were found to be firmly grounded in the Post's concern for its employees and their benefits, and not in thwarting hostile advances by Newhouse. Furthermore, the plan had been conceived well before any takeover events had developed. ${ }^{91}$

number of shares to vest control of the Post in the Bonfils family and employees under its domination. See Herald, 472 F.2d at 1083-91.

83 Id. at 1091 .

84 The court stated that "[s]uch a newspaper is endowed with an important public interest. It must adhere to the ethics of the great profession of journalism." The court also described the newspaper as a "quasi-public institution." Id. at 1095.

$85 \mathrm{Id}$. at 1093.

86 See id. at 1092.

87 Id. at 1095.

88 See id. at 1084.

89 See id.

90 See id. at 1096.

91 See id. at 1095-97. 
The discussion by the Tenth Circuit of the Post's "Employees Stock Trust Plan" may foreshadow the method in which courts will examine directors' fiduciary responsibilities under nonshareholder constituency statutes. By analyzing the Post's role in providing benefits to workers, the court may have correctly focused upon the directors' attempts to aid or accommodate significant stakeholder interests. ${ }^{92}$ If a court was faced today with a nonshareholder constituency statute, it might decide whether the directors had, through a benefits program (contracting process), sufficiently considered employees' (stakeholders') interests ex ante to a takeover and therefore satisfied their statutory responsibilities.

\section{Contracting Wrthout Entitlements}

Stakeholders often interact with corporations on a continued basis over a long period of time. Expectations are created between stakeholders and corporations either through contracting processes or through community interaction. For example: managers expect compensation and security in employment; labor expects to sign, and perhaps negotiate, contracts for employment; ${ }^{93}$ suppliers and buyers expect to contract for goods and services; ${ }^{94}$ bondholders expect fixed returns for their investments; ${ }^{95}$ and local communities expect jobs, adequate working conditions, and clean and safe environs. ${ }^{96}$ These expectations may be frustrated with a change of con-

92 The court specifically noted that the "Post's concern for their employees is exemplified in all the employee benefits provided.... Indeed, approximately $11 \%$ of the Post's total expenses go for these employee benefits." Id. at 1095. A more recent evaluation of the validity of an employee stock ownership plan in a takeover context can be found in Shamrock Holdings, Inc. v. Polaroid Corp., 559 A.2d 257 (Del. Ch. 1989). The Chancery Court's examination of Polaroid's plan was in a slightly different context than Herald, since Polaroid had approved and implemented a major part of its plan in the midst of a takeover context. See infra notes 212-18 and accompanying text.

93 See, e.g., Raday, supra note 13, at 141 ("From the employee's perspective, individual job security means that he has a right to his job ...."); Singer, supra note 13 , at 728-29 ("While it is true that workers and managers will bargain around compulsory contract terms, the resulting bargain will vary depending on their relative bargaining power.").

94 See, e.g., Singer, supra note 13, at 719 (examining the impact of a plant closing on supporting businesses).

95 See, e.g., McDaniel, Bondhoiders and Corporate Governance, 41 Bus. LAw. 413, 418 (1986) ("The potential for bondholder-stockholder conflict exists because bondholders have prior but fixed claims on a firm's assets while stockholders have limited liability for the firm's debt and unlimited claims on its remaining assets.").

96 See, e.g., Coffee, supra note 7, at 71-73 ("[S]tate and local communities frequently stand in the position of a creditor or partial surety for the corporation."). 
trol: new owners may attempt to renounce or renegotiate existing agreements or contracts. ${ }^{97}$ The corporation or firm as "a nexus for a set of contracting relationships among individuals" 98 may undergo a vast transformation as a result of a hostile acquisition, attempted acquisition, or restructuring. At least in the hostile takeover context, the surviving corporation may be highly leveraged. ${ }^{99}$ Stakeholders, who have sunk substantial investments into the corporation, may face an uncertain future, ${ }^{100}$ while shareholders are cashed out of their ownership positions. ${ }^{101}$

Shareholders might claim that they had supported the corporation as "residual claimants or residual risk bearers," since their shares entitled them only to the "rights to net cash flows" from the corporation. ${ }^{102}$ Under this contractual view of the corporation, shareholders assume most of the risk of the corporation, while all stakeholders who have a direct relationship with the firm supposedly are protected through fixed contractual agreements. ${ }^{103}$ To maximize returns, however, the corporation must attempt to minimize agency costs, which "include the costs of structuring, monitoring, and bonding a set of contracts among agents with conflicting interests." 104 These agents are usually managers, employees, and creditors. For example, managers are hired as agents of the corporation to carry out "decision management and decision control."105 It is

97 See Davis, Epilogue: The Role of the Hostile Takeover and the Role of the States, 1988 Wis. L. REv. 491, 516-17.

98 Jensen \& Meckling, Theory of the Firm: Managerial Behavior, Agency Costs and Ownership Structure, 3 J. Fin. Econ. 305, 310-11 (1976).

99 See Lipton, supra note 25, at 20-23.

100 For example, employees have often invested many years of service and uncompensated time and labor in corporations and have less of an ability to leave their jobs. See Singer, supra note 13, at 715-17; Summers, supra note 16, at 170.

101 See, e.g., Coffee, supra note 18, at 440 (noting that stakeholders "are exposed ... to shareholder opportunism").

102 See Fama \& Jensen, Separation of Ownership \& Control, 26 J.L. \& EcoN. 301, 302-03 (1983).

103 See id. at 302-03; Hart, An Economist's Perspective on the Theory of the Firm, 89 Colum. L. Rev. 1757, 1763-65 (1989).

104 Fama \& Jensen, supra note 102, at 304. Fama and Jensen conclude: "In complex organizations, the benefits of diffuse residual claims and the benefits of separation of decision functions from residual risk bearing are generally greater than the agency costs they generate, including the costs of mechanisms to separate the management and control of decisions." Id. at 309; $c f$. Baysinger \& Butler, Antitakeover Amendments, Managerial Entrenchment, and the Contractual Theory of the Corporation, $71 \mathrm{VA}$. L. REv. 1257, 1272-73 (1985) ("The system of corporate law provides a number of formal institutional arrangements that also operate to reduce agency costs in large corporations.").

105 Fama \& Jensen, supra note 102, at 304-05. 
assumed that they do not bear the same magnitude of risk as shareholders ${ }^{106}$ and are guaranteed a fixed rate of return (compensation) through established contractual agreements. ${ }^{107}$ Alternatively, in return for bearing risk, "stockholders are not required to have any other role in the organization, and their residual claims are freely alienable."108

The problem with this analysis is that it assumes that stakeholders do not share in any residual risk. ${ }^{109}$ It is possible, though, that stakeholders do share in substantial risks created through takeovers. ${ }^{110}$ Contracts that have been negotiated before the takeover period frequently do not include contingencies for the negotiation of additional risk-sharing among the parties should a takeover occur. For example, employment contracts usually do not include consideration for employees' expectations that exist as a result of their investment of human capital in corporations. ${ }^{11}$

If a company has been purchased by a hostile raider, the original shareholders have been cashed out of their holdings at a significant premium. Employees, however, are left behind and are at the mercy of the raider's plans for the future. Therefore, a takeover may result in ex post losses to groups who hold contracts that do not account for higher levels of risk or expectations. ${ }^{112}$ Takeover attempts may also have significant negative effects on employees. After a takeover offer, a target company may restructure by becoming highly leveraged. ${ }^{113}$ Employees face new uncertainties of losing their jobs, as

106 See id. at 304.

107 See Coffee, supra note 7, at 12; cf. Coase, The Nature of the Firm, reprinted in Economics of Corporation Law and Securities Regulation 3, 4-5 (R. Posner \& K. Scott eds. 1980) (concluding that markets and firms are alternative forms of contracting and that transaction costs determine how to choose between them). For a listing of relevant works discussing the contractual economic theory of the firm, see Bratton, The New Economic Theory of the Firm: Critical Perspectives from History, 41 STAN. L. REv. 1471, 1476 n.22 (1989).

108 Fama \& Jensen, supra note: 102, at 312.

109 See Coffee, supra note 7, at 12.

110 See id.

111 See id. at 74-75; Raday, supra note 13, at 148-49. In terms of plant closings, one scholar notes, "In the real world, investors are often more secure than workers, and they are secure because they shift many of the risks of investment onto workers and communities by closing plants rather than by bearing the costs of creating profitable and productive enterprises with those workers." Singer, supra note 13, at 728.

112 See Coffee, supra note 7, al. 72.

113 See L. Solomon, D. Schwartz \& J. Bauman, supra note 2, at 1131. 
“[p]art of the plan is likely to call for sales of whole divisions . . . so as to be able to service the new debt."114

Nonshareholder constituency statutes may provide directors and officers with a foundation in which to consider the problem of risk borne by stakeholders after a takeover or restructuring. Directors and officers might fashion certain explicit contracts which would protect stakeholders from the added risks created by changes of control and capital structure. They might offer and negotiate these contracts well before any takeovers are initiated. The contracts would offer continuity of employment, bonding, or ownership rights agreements and would represent a system of premium sharing, since they might impact on the purchase price of the corporation. ${ }^{115}$ Although the price offered for the corporation with these agreements might be lower in a takeover, the difference would lie in the value of the contracts (which benefit employees). Once the contracts have been made, thus entitling stakeholders to a "piece of the takeover action" or a portion of the potential wealth gains or transfers, directors may turn their attention to shareholder wealth maximization. ${ }^{116}$ At that point, their responsibilities under nonshareholder constituency statutes would be satisfied.

\section{Providing Labor With Explicit Contractual Protection}

Non-managerial employees constitute a significant stakeholder group that experiences increased risk from hostile takeovers. ${ }^{117}$ There have been many examples of corporations that have leveraged their balance sheets as a takeover defense and subsequently dismissed or retired large portions of their workforce. ${ }^{118}$ Pension plans

114 Id; see also Coffee, supra note 7, at 72 (noting that employee lay-offs often occur after a corporate restructuring).

115 See, e.g., Jensen, supra note 31, at 39-45 (outlining some of the costs of antitakeover measures and their impact on the purchase price of corporations).

116 See Revlon, Inc. v. MacAndrews \& Forbes Holdings, 506 A.2d 173, 182 (Del. 1986) (concluding that once it is apparent that the corporation is to be sold, the duty of directors changes to auctioneers, charged with maximizing the price for the stockholders).

117 This may also be the case for managerial workers. See, e.g., Halverson, First the Merger, Then the Job Cut, Christian Sci. Monitor, Aug. 4, 1989, at 9 ("The mergeracquisition fervor of the past decade has led to some layoffs of workers ... particularly among professionals at the managerial level and among highly paid skilled workers within the manufacturing sector.").

118 For example, Prime Computer Corp. avoided being taken over by MAI Basic Four, Inc. by accepting a leveraged buyout by J.H. Whitney \& Co. The buyout resulted in burdening Prime Computer with over one billion dollars in debt and 150 million dollars in annual interest payments. By October, 1989, the Company 
have been terminated or excess funds from those plans have been used to provide cash to leveraged corporations struggling to maintain liquidity. ${ }^{119}$ Hostile purchasers or leveraged buyout firms often consolidate, restructure, bust-up, or liquidate whole portions of corporations, leading to plant closings ${ }^{120}$ and terminations of workers. ${ }^{121}$ In addition, employees are usually members of local

announced that it would layoff approximately 2,500 employees (21 percent of its total workforce). The Company stated that the firings were part of a company-wide restructuring which would reduce its outstanding debt and cut significant costs. See Edelman, Prime to Lay Off 2,500 More; State to Feel the Brunt, Boston Globe, Oct. 24, 1989 , at 1 , col. 2. In response to a hostile bid by Wickes Corporation in late 1986, Owens-Corning reduced its pre-takeover bid workforce of 28,000 by approximately 13,000 workers as a result of increased leverage and restructuring. See Faludi, Safeway LBO Yields Vast Profits but Eiracts A Heavy Human Toll-The '80s-Style Buy-Out Left Some Employees Jobless, Stress-Ridden, Distraught, Wall St. J., May 16, 1990, at A1, col. 6; O'Brien \& Kline, An Rx for Jobs Losi: Through Mergers, N.Y. Times, Feb. 22, 1987, § 4, at 23, col. 2; see, e.g., Cummins Engine to Lay Off 49 Production Workers In Indiana, McGrawHill News, March 23, 1989; see also supra notes 12 \& 39 and accompanying text (arguing that takeovers and restructurings result in the elimination of jobs).

119 On the issue of employment, pension plans, and takeovers, Senator Proxmire recently stated:

Takeovers have led directly to the elimination of jobs. AFL-CIO officials estimate that takeovers have caused the loss of 80,000 union jobs. In the aggregate, some 500,000 jobs have been lost. . . A American workers are plundered even when they are not terminated. For example, some $\$ 16$ billion has been siphoned from private pension plans. In many cases, the plundered funds went to firms attempting to fend off a bidder, or even to successful bidders.

Proxmire, supra note 39, at 360 (footnotes omitted); see also Coffee, supra note 7 , at $70-71$ \& n.194 ("Over the last five years, employers have terminated more than 700 pension plans and collected $\$ 6.7$ billion in 'surplus' assets; $\$ 3$ billion was recaptured in 1984, equal to the three previous years and thus showing a rising tide."); Williams, Raking in Billions From the Company Pension Plan, N.Y. Times, Nov. 3, 1985, at F1, col. 2 ("At an increasing pace, some of the most familiar names in corporate America ... have already withdrawn, or are trying to withdraw, $\$ 8$ billion in surplus pension money. They are diverting this money to other corporate uses, such as takeover financing and capital investment ....").

120 See, e.g., Singer, supra note 13, at 614-620 (outlining some of the sources and effects of plant closings).

121 See, e.g., A Freeze on the Frenzy, Newsday, Oct. 22, 1989, at 4 ("RJR Reynolds Tobacco USA has cut its 15,000-person workforce by 2,340 since the takeover [leveraged buyout by Kohlberg, Kravis, Roberts \& Co.]. An additional 300, or 10 percent, were cut in RJR Nabisco's food operation, based in New Jersey."); Walker, RJR Tobacco Unit to Eliminate 1,640 Jobs in Restmucturing, Reuter Bus. Report, Aug. 10, 1989 ("R.J. Reynolds said it would cut 1,640 salaried and hourly workers, reducing its staff to around 12,500."); Hinden, Retired RJR Official Issues Warning on LBO; Debt is Likely to Mean Layoffs, Cost-Cutting, House Panel Told, Wash. Post, Feb. 9, 1989, at E2, col. 4 ("Layoffs, reduced employee benefits and deep cost-cutting at RJR Nabisco Inc. will be the bitter fruit of the $\$ 25$ billion takeover by the investment firm of [KKR], a retired RJR official predicted . . . ."); Regenstrelf, Campeau Says Shakeup of Federated Is Complete, Reuter Bus. Report, June 30, 1988 ("Robert Campeau . . . fired 
communities (additional stakeholders) that may be affected by layoffs or terminations. ${ }^{122}$ Although it may be argued that these developments generally represent corporate responses to increased economic competition from abroad, ${ }^{123}$ it does not answer the question, "should workers be compensated for bearing higher levels of risk?" Nonshareholder constituency statutes clearly indicate that the interests and expectations of workers should not be ignored. ${ }^{124}$ Directors and officers may acknowledge such expectations by offering to negotiate explicit risk-sharing contracts with workers.

Directors and officers may be able to reduce the costs to labor of employment termination by offering to negotiate contracts similar to those used by many corporations. If the employees are mostly members of labor unions the use of successorship clauses in collective bargaining agreements may offer a source of group protection for workers' interests in event of a change of control. If the employees are not unionized, silver or tin parachute agreements might protect workers. In either case, employee stock ownership plans, adopted well in advance of any takeover activity, might greatly assist in reducing employees' added risks from takeovers. ${ }^{125}$

more than 3,600 Federated Department Stores Inc. workers since taking over the firm in May ...."); Prokesch, People Trauma in Mergers, N.Y. Times, Nov. 19, 1985, at D1, col. 3, D5, col. 1 ("In an effort to slash overhead through [consolidation] ... acquiring companies ... have discharged or pushed into early retirement tens of thousands of people.").

122 See supra note 11 and accompanying text; see also Singer, supra note 13, at 718 (outlining the effects of plant closings on workers, their families, and communities).

123 This competition has, in turn, created the need for more efficient management or pruning of surplus workers, redundant resources, and excess capacity. This may be especially true in the oil industry takeovers of the early- to mid-1980s. See Coffee, supra note 7, at 70 n.193 \& 71.

124 See supra note 51 and accompanying text.

125 No attempt will be made to distinguish between specific highly-regulated and non-regulated industries. However, directors of corporations that are highlyregulated by the federal government may face additional statutory and administrative duties requiring them to consider protective agreements or contractual provisions for workers who are adversely affected by mergers. For example:

[A] comprehensive system of governmental regulation in the transportation industry has included as an incident far-reaching protective provisions for employees adversely affected by mergers . . . in the form of severance pay in the event of dismissal, displacement allowances for poorer jobs, moving and retraining allowances, and protection of seniority.

Blumberg, Collective Layoffs: Protection of Employees Against Dismissal or Displacement as a Result of Mergers, Closings, or Work Transfers, 26 AM. J. CoMP. L. 277, 284 (Supp. 1978). 


\section{A. Successorship Clauses}

Collective bargaining agreements may contain clauses which make the contract binding on any successor or assignee. These clauses purport to bind the successor or purchaser of a business to the unexpired collective bargaining agreement of the predecessor. ${ }^{126}$ Detailed provisions "may make the contract binding on the company's successor in the event of a sale, transfer, merger, or other change in the form of the business." 127 During collective bargaining, unions usually demand successorship clauses, while employers generally oppose them. ${ }^{128}$ Since the National Labor Relations Board has held that successorship clauses constitute a mandatory subject of bargaining, ${ }^{129}$ employers must seriously consider unions' demands.

In several cases, the Supreme Court has considered the enforceability of labor agreements on successor corporations. In NLRB $v$.

126 There are several different. types of successorship clauses. The first, which involves "boilerplate recitals" either in the preamble or final paragraph of the agreement, simply states that the contract is binding on the parties and their successors or assigns. The second type has been called an "evasion clause" since the employer often promises not to transfer any operation or business "for the purpose of defeating or evading the agreement." In the third type, the "explicit successorship clause," "the employer expressly agrees to transfer the operation only to a purchaser who will assume the labor contract." Estreicher, Successorship Obligations, in LABOR LaW and Business Change 63, 68 (S. Estreicher \& D. Collins eds. 1988). References to a successorship clause in this Comment are generally to the third type of clause.

127 Collective Bargaining Agreements Negotiations and Contracts (BNA) 70:181, at 141 (Sept. 10, 1987). For example, a successorship clause within a collective bargaining agreements states:

Contract binding regardless of any change in geographical or otherwise, in location or place of business of either party ...

This Agreement shall be binding upon the successors and assigns of the parties hereto, and no provisions, terms or obligations herein contained shall be affected, modified, altered or changed in any respect whatsoever by the consolidation, merger, sale, transfer or assignment of either party hereto, or affected, modified, altered or changed in any respect whatsoever by any change of any kind of the ownership or management of either party or by any [sic] change, geographical or otherwise, in the location or place of business of either party hereto.

Id. at 142.

128 See Comment, Successorshit Clauses in Collective Bargaining Agreements, 1979 B.Y.U. L. REv. 99, 102.

129 See UMW (Lone Star Steel Co.), 231 N.L.R.B. 573, 575 (1977). Although the NLRB held that successorship clauses are mandatory subjects, they did not examine the "issues of whether a union may lawfully act to compel compliance with such a provision or whether a successor employer would be bound by the terms of such an agreement." Id. at 575 n.13. 
Burns International Security Services, Inc., ${ }^{130}$ the Supreme Court firmly established that a successor is not bound by a predecessor corporation's labor agreements; ${ }^{131}$ the case, however, did not involve a successorship clause. In Howard Johnson Co. v. Detroit Local Joint Executive Board, ${ }^{132}$ the Court was faced with a successorship clause in a collective bargaining agreement and a change of control. The Court did not "reach the question of whether the parties to a labor contract could alter successorship liability via an express agreement."133 Instead, it found that the buyer was not required to arbitrate with the union since there was no continuity of identity in the work force hired by the buyer, compared to that of the seller, and in addition, there was no express or implied assumption by the buyer of the arbitration agreement. ${ }^{134}$ The Court did explain that another remedy might be available to the union: moving to enjoin the sale on the grounds that it was a breach of the successorship clause in the collective bargaining agreement by the seller. ${ }^{135}$ Applying the Burns and Howard Johnson opinions together, circuit courts have held generally that successorship clauses, of any form, cannot be enforced against unwilling buyers. ${ }^{136}$ Thus, courts have held that successorship clauses are not binding on successors without their consent to all of the substantive terms and conditions of predecessors' collective bargaining agreements. Courts have been consistent in applying contract law, holding that a party cannot be bound by a contract to which it did not consent. ${ }^{137}$

Although successorship clauses may not be legally binding upon buyers, they may achieve the same result by providing the union with an opportunity to enforce the clauses upon sellers through injunctive relief or damages. In Local Lodge No. 1266, International Association of Machinists $\mathcal{E}$ Aerospace Workers v. Panoramic Corp., ${ }^{138}$ the Seventh Cir-

130406 U.S. 272 (1972).

131 See id. at 291.

192417 U.S. 249 (1974).

133 Comment, The Unenforceable Successorship Clause: A Departure From National Labor Policy, 30 UCLA L. REv. 1249, 1266 (1983) (footnote omitted).

134 See Howard Johnson, 417 U.S. at 264-65.

135 See id. at 258 n.3.

136 See, e.g., Bartenders and Culinary Workers Union, Local 340 v. Howard Johnson Co., 535 F.2d 1160, 1162-63, (9th Cir. 1976) (refusing to enforce a successorship clause against a successor who had retained the entire workforce of its predecessor); Emerald Maintenance v. NLRB, 464 F.2d 698, 701 (5th Cir. 1972) (refusing to enforce a successorship clause against a successor who had hired a majority of its employees from a predecessor's workforce).

137 See Comment, supra note 128, at 105.

138668 F.2d 276 (7th Cir. 1981). 
cuit held that a union was allowed injunctive relief to halt a proposed sale of corporate assets. The injunction was granted pending arbitration of the employer's right to sell the business without ensuring adoption of the collective bargaining agreement, which included a successorship clause, by the purchaser. ${ }^{139}$ The court found that "the decision to sell the Sintered. Specialties Division [of Panoramic Corporation] threatened the Union and its members with irreparable injury." 140 Other courts have allowed damage remedies for breach of successorship clauses. ${ }^{141}$

A union may gain injunctive relief only if it files a suit prior to the consummation of the transaction. Therefore, the union must know or be informed about the pending sale, restructuring, or liquidation of the company in order to file a suit for injunctive relief. ${ }^{142}$ In most hostile takeover settings this will not be a problem, since bidders publicly announce tender offers for the benefit of shareholders. ${ }^{143}$ The threat of injunction will cause the seller to require that any acquiror satisfy the terms of any existing successorship clauses. The seller will probably ask that any acquiror indemnify it against any related suits under any such clauses. Therefore, the successor-

139 See id. at 277,279 . The successorship clause at issue was contained in the preamble to the collective bargaining agreement. The union (plaintiff) interpreted the "successor and assigns" clause "as requiring Panoramic to secure from any purchaser, as a condition of sale, an assumption of the obligations of the labor agreement." Id. at 279 . The court agreed with this interpretation.

$140 \mathrm{Id}$. at 288 . On the issue of harm to union employees and the possibility of a damage (breach of contract) remedy, the court stated:

The proposed sale of Sintered Specialties Division would have resulted in the immediate loss of employment by 113 Panoramic workers represented by the Union. The purchaser . . . has no duty to rehire these employees and has expressed no specific desire to do so. Where, as here, employer action threatens a permanent loss of jobs, a damage remedy is inadequate.

Id. at 286. The Ninth Circuit is the only court to take a position counter to this holding. It has indicated that "such injunctions will not issue in the absence of an express clause obligating the employer to preserve the status quo pending arbitration, although it too has left open the possibility of an injunction for situations in which the arbitrator will not be able effectively to restore the status quo." Estreicher, supra note 126, at 70. Most courts, however, appear to be satisfied with a broad arbitration clause and some type of successorship clause. Courts have been influenced by the "prospect of permanent loss of jobs by union members and the inability of the arbitrator to fashion an effective remedy once confronted with the fait accompli of a consummated assets sale and transfer of operations." Id.

141 See Fasman \& Fischler, Labor Relations Consequences of Mergers and Acquisitions, 13 EMPLOYEe REL. L.J. 14, 27 (1987) ("[T]he success of any damage theory will depend upon whether the contracl. clause imposes specific enforceable duties upon the predecessor employer.") (footnote omitted).

142 See id.

143 See L. Solomon, D. Schwartz \& J. Bauman, supra note 2, at 1052. 
ship clause would appear to be a legitimate means of protecting labor contracts after a takeover.

A board that has approved a successorship agreement has thus accepted the fact that any future acquirors must be required to honor collective bargaining agreements. The purchase price paid for the corporation will reflect the cost of such contracts; the board will have capitalized part of the corporation's labor costs into the corporation's acquisition price. This represents an entitlement to a stakeholder group, negotiated in advance of an acquisition. If a hostile bid is then made for the corporation, and if the directors have already agreed to a successorship clause, labor's entitlements may have been examined and accounted for as described in nonshareholder constituency statutes. The board may then turn its attention to shareholders' and other stakeholders' concerns.

\section{B. Silver or Tin Parachutes}

One form of explicit contracting in advance of a takeover that has already been used by many corporations ${ }^{144}$ is the "golden parachute." 145 These contracts represent explicit agreements between officers and corporations in which the corporation agrees to pay certain benefits in the event of a change in control. The agreements provide a guarantee of the financial security of executives, ${ }^{146}$ since

144 See, e.g., Haims \& Cagney, Guidelines for a Change of Control Audit, Nat'l L.J., Sept. 25, 1989, at S2, col. I (" $[I]$ n 1988, 41 of the top 100 industrial companies provided change of control protection for one or more executives, compared with only 12 five years earlier, and 55 percent of 242 U.S. industrial and financial organizations provided golden parachute protection in 1988.") (footnotes omitted).

145 A typical golden parachute plan protects corporate officers in the event that their employment is terminated on or subsequent to a change in control of the corporation. Severance benefits are paid to an officer if the corporation terminates the executive (other than for "cause") or if the officer "terminates his employment because there have been specified actions short of termination taken with respect to his employment, such as downgrading of position, a reduction in salary, a forced relocation or a failure to maintain bonus or benefit plans." 2 SHARK REPELLANTS, supra note 61 , at 425 . The term "golden parachute" is often used as a "pejorative term for a contract, generally made only with senior management, that provides substantial benefits if the executive leaves the employ of the target corporation, or at least is forced to leave, after a change in control." L. Solomon, D. Schwartz, \& J. BaUman, supra note 2, at 1061 . Thus, it is thought that the generous benefits offered by such plans provide a "safe landing" for corporate officers in the event of a takeover. See 2 Shark Repellants, supra note 61, at 425 . However, no negative connotations should be drawn from the use of the term in this Comment.

146 See Subcommittee on Executive Compensation, $A$ Road Map for the Corporate Advisor, 40 Bus. LAw. 219, 348-49 (1984). For an introduction to the mechanics of a golden parachute agreement, see 2 SHARK REPELIANTS, supra note 61, at 425-436.8. 
officers are exposed to significant risks in two areas: human capital and deferred compensation. ${ }^{147}$ Officers will not have incentives to develop firm-specific skills or expertise if it is apparent that such investments will be lost as a result of a takeover. In addition, they will not be willing to defer compensation if there is an inherent risk of termination or change of position. The corporation can compensate managers for the risk of termination by either offering to pay a risk premium or using "bonding devices, such as the 'golden parachute,' which compensates only those who are in fact terminated."148

The use of a bonding mechanism, if reasonably created, ${ }^{149}$ may protect the interests of managers throughout a takeover and offer them incentives to maximize shareholders' value. In fact, the contracts represent a means of eliminating the conflict of interest between target management and shareholders with respect to a takeover. ${ }^{150}$ Officers may thus be in a better position to bargain for risk-

For a list of commentators and bibliography of articles related to the validity and enforceability of golden parachutes, see id. at 435 n.l.

147 See Coffee, supra note 7, at 74-75; Raday, supra note 13, at 149-50.

148 Coffee, supra note 7 , at 74 .

149 The Tax Reform Act of 1984 (and as amended by the Tax Reform Act of 1986) established statutory thresholds for parachute payments. The Internal Revenue Service does not have authority to challenge the corporation's right to contract for large parachute payments or the executive's right to receive them. However, the Service may attack the ability of the corporation to take a tax deduction on the payments. See 26 U.S.C. $\$$ 280G, 4999 (Supp. II 1984 \& Supp. V 1987). Section 280G of the Internal Revenue Code disallows corporate tax deductions for "payments in excess of reasonable compensation for 'golden parachute' payments to key employees upon a change of ownership or control .... An 'excess parachute payment' is generally defined as a payment whose aggregate present value exceeds three times the average annual compensation includible in the recipient's gross income over the preceeding five-year period." M. Graetz, FEDERAL Income TAXATION 287 (2d ed. 1988). Congress enacted section 4999 of the Internal Revenue in order to "impose a 20 percent excise tax on excess parachute payments." Id. In addition, the Securities and Exchange Commission has required increased disclosure of golden parachutes. See Regulation S-K, 17 C.F.R. $\$ 229.402$ (e) (1989) (Item 402(e)); see, e.g., Haims \& Cagney, Guidelines for a Change of Control Audit, Nat'I L.J., Sept. 25, 1989, at S2, col. 1 (outlining steps to be taken by independent directors in creating a valid change of control provision and the current SEC rules). For discussions of unusually large or excessive golden parachute agreements, see Greenhouse, Golden Chutes Under Attack, N.Y. Times, Dec. 10, 1985, at D2, col. 1; Johnson \& Morris, Beatrice Cos. Grants Golden Parachutes Totaling $\$ 23.5$ Million to Six Officials, Wall St. J., Nov. 25, 1985, at 4, col. 1 .

150 See, e.g., R. GiLson, supra note 41, at 670-71 ("Awarding management golden parachutes adds a second asset to management's portfolio: the expectation of a large termination payment which can be realized only if a takeover actually occurs. The result, it is argued, is a portfolio the value of which is invariant to the risk of takeover. As a result, management will consider a proposed offer solely from the perspective of what is best for the shareholders ...."). 
bearing compensation than most other stakeholders. This does not mean, though, that other employees should be left out of an advanced contracting process.

The golden parachute might be extended to mid-level management ("silver") or rank and file workers ("tin") in non-unionized companies. These plans have also been called parachute agreements and are designed to provide severance compensation to workers after a hostile takeover. ${ }^{151}$ The board of directors might develop a parachute plan available to all full-time employees of the corporation, establishing a contractual right to the benefits under the plan. Eligibility might hinge upon a minimum number of years an employee has spent with the company and a change of control of the corporation. Following a takeover, the eligible employee would be entitled to a "parachute payment" if her employment is terminated involuntarily. The amount of the payment might be correlated to the number of years that the employee has been with the firm. The corporation would require that any successor or assignee, through purchase, merger, hostile acquisition, or otherwise, expressly and unconditionally assume and agree to perform the corporation's obligations under the plan. ${ }^{152}$

In general, courts have upheld the enforceability of golden parachute agreements, rejecting arguments that such agreements are a waste of corporate assets or are not supported by adequate consideration. ${ }^{153}$ For example, one court held that a golden parachute agreement in question was enforceable since it was executed for the

151 See 2 ShaRk Repelients, supra note 61 , at 591. The introduction to a model silver parachute agreement states:

Many employees have invested their lives in their jobs and have made significant contributions to the growth and success of the Company. The stress on the employees and their families caused by the uncertainties of the pre-takeover contests and by the post-takeover threats resulting from the change in control are widely recognized. Plant shutdowns, plant relocations, different management ... . and reduced employee benefits all may flow from a hostile takeover, and all impose costs which must be borne by the employee and the employee's family.

The Board of Directors recognizes that, after a hostile takeover of the Company, it will no longer have the power to protect the interests of the employees. The Board believes it is in the Company's interest to provide employees with the right to compensation to assist them in bearing the costs imposed by a hostile takeover.

Id.

152 See id. at 592-99. This Comment suggests that the silver or tin parachute extend to situations involving non-hostile takeovers or perhaps even restructurings.

153 Litigation challenging golden parachute plans has been largely unsuccessful on procedural grounds and on the merits. See id. at 436.1 . 
purpose of protecting stockholders by inducing the corporation's officers to remain at work during a time of uncertainty when they might otherwise be distracted by concerns for their own financial security. ${ }^{154}$ Another court rejected a waste of corporate assets claim and upheld an agreement on the grounds that the severance compensation provided to an executive was "comparable to severance pay provided employees in other contexts." 155 It appears, however, that in order for a golden parachute to be enforced, its terms must be related to the termination of an executive (or employee) and not simply to a change in control. ${ }^{156}$ In addition, two other factors may influence a court's willingness to enforce a parachute agreement: the approval of the agreement by a disinterested majority of the board of directors or a board committee, and the approval by the corporation's shareholders, after appropriate disclosure. ${ }^{157}$ Unfortunately, relatively few cases have involved the enforceability of golden, silver, or tin parachutes, which increases the difficulty of predicting the outcome of specific agreements. ${ }^{158}$

In any event, silver or tin parachute plans represent a low$\operatorname{cost}^{159}$ means of wholesale contracting for employees' rights.

154 See Royal Crown Co. v. McMahon, 183 Ga. App. 543, 545-46, 359 S.E.2d 379,381 (1987).

155 Ohio Court Rejects Challenge to Bank Employee's "Golden Parachutes," 18 Sec. Reg. \& L. Rep. (BNA) 1719, 1719 (1986).

156 See, e.g., Buckhorn, Inc. v. Ropak Corp., 656 F. Supp. 209, 233-35 (S.D. Ohio), aff'd by summary ord., 815 F.2d 76 (6th Cir. 1987) (enjoining enforcement of an amendment to a golden parachute agreement adopted in response to a takeover threat, authorizing the corporate officer to terminate employment with the corporation and receive severance pay solely on the basis of a change in control, regardless of adverse actions with respect to his employment status).

157 See 2 Shark Repellants, supra note 61, at 436.7; see, e.g., Ryan, Corporate Directors and the "Social Costs" of Takeovers-Reflections on the Tin Parachute, 64 TuL. L. REv. 3, 19 (1989) ("Typically, a tir parachute plan is adopted by a board of directors' resolution without the need for shareholder approval although it is possible for a board to seek ratification of its decision to adopt a tin parachute.").

158 See 2 Shark Repellants, supra note 61, at 435. According to one source:

[T] here is relatively little precedent to date on the merits [of enforceability of parachute plans] because, in part, litigation which is instituted in the context of a hostile takeover frequently does not result in decisions on the merits and there are conflicts in the courts as to when it is appropriate to examine the merits of such agreements ....

Id. (footnote omitted).

159 See Ryan, supra note 157, at 19. Ryan notes that, for silver parachutes:

[L]egal drafting fees are low, at least when compared with other forms of legal services. Further, no corporate monies need be expended to install the plan because no payments are required until job actions follow a hostile takeover. Finally, neither accounting guidelines nor government 
Although a plan would not represent an employment contract or a job-status guarantee under a change of control, it would provide for a contractual payout if an employee is terminated or moved to an inferior position. ${ }^{160}$ The potential payout would have an impact on the company's purchase price, representing a transfer of compensation from stockholders to employees. ${ }^{161}$

Herman Miller, a producer of office furniture in Michigan, was the first corporation to adopt this type of plan. ${ }^{162}$ All employees with a minimum of two years of.service are eligible for at least one year's pay if they are terminated, or experience reduced salaries, benefits, or working conditions as a result of a takeover. Employees who have been with the company for more than five years are eligible to receive 2.5 times their total compensation for the previous year, but not more than 2.99 percent of their average annual pay during the preceding five years. At the time of the adoption of the plan, Herman Miller's chairman stated that the corporation was not the target of any takeover attempts. ${ }^{163}$

regulations require companies to establish a reserve account for anticipated tin parachute payments.

Id. (footnote omitted).

160 See 2 Shark REPELLANTS, supra note 61, at 597.

161 See Coffee, supra note 7, at 70, 104-05.

162 Herman Miller's plan was adopted in 1986. Since that time a number of companies have adopted tin parachute plans. One scholar has recently conducted a search for corporations that have adopted silver or tin parachute agreements. See Ryan, supra note 157, at 10-11 n.17. He first requested a list from the Investor Responsibility Research Center ("IRRC") of corporations which have adopted such plans. The IRRC identified 19 corporations, including: Accuray Corp.; Amstrong World Indust., Inc.; Chesebrough-Ponds, Inc.; Fireman's Fund Corp.; First Tenn. Nat'l Corp.; W.W. Grainger, Inc.; Irving Bank Corp.; Lubrizol Corp.; Maxus Energy Corp.; Mead Corp.; Mellon Bank Corp.; Herman Miller, Inc.; Mobil Corp.; Oneok, Inc.; Optical Coating Laboratory, Inc.; Orange \& Rockland Utilities, Inc.; Polaroid Corp.; San Diego Gas \& Electric Co.; and Westvaco Corp. See id. Both Accuray and Chesebrough-Ponds's were acquired through "friendly" takeovers. Irving Bank's tin parachute was apparently used as a takeover defense against a hostile bid by the Bank of New York. Ultimately, Irving Bank was acquired by the Bank of New York and "tin parachute benefits [were] paid to discharged [Irving] employees, at the rate of one month's salary for each year of employment, to a maximum of 24 months' compensation." Id.

Ryan then examined the proxy statements of the companies on the IRRC list and compiled a comprehensive appendix, comparing characteristics of the plans. Interestingly, the majority of the plans were "linked to [a change] of control" and all of the plans were adopted without shareholder approval. See id. app. at 68-70.

163 See Herman Miller Adopts Company-Wide "Parachute," Oct. 9, 1986, United Press Int'l Tape (Fin.); Silk, The Great Freedom of Corporate Life: To Question, Bus. MoNTH, Apr. 1989, at 11; Lawrence, Why Golden Parachutes are Fool's Gold, L.A. Times, Oct. 26, 1986, \& 5 (Bus.), at 1, col. 1 . 
The Herman Miller plan represents a legitimate example of corporate directors considering and accounting for significant stakeholder interests. The directors adopted a specific arrangement to compensate workers in the event that they become victims of a restructuring or liquidation after a takeover.

\section{Employee Stock Ownership Plans ("ESOPs")}

Non-managerial and mid-level managerial employees usually do not own and cannot borrow enough financial resources to purchase a meaningful amount of their corporation's stock. ${ }^{164}$ The leveraged or non-leveraged employee stock ownership plan provides a means for the "government to put ownership in the hands of people who could not otherwise afford it or achieve it through most efforts of their own." 165 The federal government has created a means of encouraging companies to establish employee equity ownership plans out of retained earnings by offering either tax-advantaged credits or general tax advantages. ${ }^{166}$

An ESOP is a qualified stock bonus or stock purchase plan offered by an employer to give or sell stock to employees through a trust (often called an employee stock ownership trust, "ESOT") in exchange for tax advantages. Qualifications and limitations on contributions by employers to ESOPs are defined in the Internal Revenue Code and Regulations ${ }^{167}$ and in the Employee Retirement Income Security Act of 1974. ${ }^{168}$ Employers' contributions to ESOPs are usually tax deductible, and the value of the stock contributed is

164 See J. BLASI, EMPLOYEE 'OWNERSHIP-REVOLUTION OR RIPOFF? 117 (1988).

165 Id.

166 Tax-advantaged credits are available for the leveraged ESOP; general tax advantages are available for the non-leveraged ESOP. See id.

167 Since the late 1970s, over a dozen tax laws have been enacted which give favorable treatment to and support the adoption of ESOPs. Two significant benefits include the corporation's right to deduct both principal and interest on the loan in a leveraged ESOP and the right to deduct ESOP contributions totalling 15 to 25 percent of the compensation piaid to participants. See E. Cohen-Rosenthal \& C. Burton, Mutual Gains: A Guide to Union-Management Cooperation 252 (1987) [hereinafter Mutual GaINs]. See generally J. BLASI, supra note 164, at 33-38 (listing the significant public laws related to favorable tax treatment for ESOPs).

168 ESOPs are considered to be a type of pension plan. However, they are exempt from many of the more restrictive and costly provisions of the Employment Retirement Insurance Security Act ("ERISA"). For example, ESOPs are able to invest primarily in the employer corporation's securities and thus are not limited to the 10 percent limitation on other pension plans under ERISA. In addition, ESOPs are not considered to be subject to the funding requirements of traditional pension plans and are not covered by Pension Benefit Guarantee Corporation Insurance. See Mutual Gains, supra note 167, at 252-53. 
not included in the income of the employee until withdrawal. ${ }^{169}$ Under an ESOP, an employee may acquire stock without payment or at a price lower than the market price. ${ }^{170}$ Upon termination or retirement, an employee is entitled to receive any vested stock held by the ESOT. ${ }^{171}$

ESOPs are, in effect, statutory pension programs that invest in employer stock and provide specific tax advantages to both employer and employee. ${ }^{172}$ Over the past twenty years, Congress has converted the ESOP from a retirement account benefit to a tool of corporate finance. ${ }^{173}$ It has created the leveraged ESOP, which facilitates worker ownership of entire corporations. A typical leveraged ESOP borrows money to purchase stock in the corporation. ${ }^{174}$ The corporation then promises to contribute to the ESOP so that the loan will be paid off. While the loan is being paid off, stock is allocated to participating employees according to a particular chosen formula. The corporation is allowed to include all ESOP contributions as business expenses, writing off both the principal and interest on the loan for tax purposes. ${ }^{175}$

In a leveraged employee buyout, the corporation borrows funds from banks to purchase the outstanding shares; the leveraged ESOP trust then exchanges a note for a proportion of the stock already purchased. After the buyout, the corporation makes annual cash pension contributions (from its earnings) to the trust; the trust then

169 See J. BLASI, supra note 164 , at 53.

170 See Olson, Union Experiences with Worker Ownership: Legal and Practical Issues Raised by ESOPS, TRASOPS, Stock Purchases and Co-Operatives, 1982 WIS. L. REv. 729, 732 n.1.

171 See id. See generally H. Henn, LAws of Corporatrons 533 (1986) ("An ESOP is a qualified plan designed to provide a retirement benefit and a stake in the corporation for employees.").

172 In addition, ESOP financing may provide tax advantages to certain qualified lenders. Under section 133 of the Internal Revenue Code, certain lenders (including banks, insurance companies, and regulated investment companies) may exclude from their gross income up to $\mathbf{5 0}$ percent of the interest received on a loan to an ESOP as long as the proceeds of the loan are used to acquire qualifying securities of the corporation. See I.R.C. $\$ 133$ (1986). This may allow lenders to reduce rates of interest charged on ESOP loans, a further tax advantage. This advantage may be eliminated by a recent budget bill, approved by both houses of Congress and awaiting presidential approval. See Belford \& Greenberg, New Bill Cuts Back Tax Benefits of ESOPs in LBO Transactions, Nat'l L.J., Dec. 18, 1989, at 16, col. 1 (outlining the effects of the Omnibus Budget Reconciliation Act of 1989 (H.R. 3200 or O.B.R.A. 1989) on ESOPs used in leveraged buyout transactions).

173 See Levin, The False Promise of Worker Capitalism: Congress and the Leveraged Employee Stock Ownership Plan, 95 Yale L.J. 148, 154 \& n.24 (1985).

174 See Mutual GaINS, supra note 167, at 251.

175 See id. 
returns the funds to the corporation to repay the outstanding ESOP note; the corporation in turn repays to the banks the acquisition debt. In sum, employees are able to "finance their acquisition of company stock with funds borrowed by the corporation and repaid with firm earnings that have been channelled through the trust as pension contributions." 176 Thus, it is apparent that Congress established leveraged ESOPs in order to address perceived inequities in the distribution of capital throughout the economy. ${ }^{177}$

Although Congress has provided a tax-subsidy framework for ESOPs, it is up to the management of corporations to decide how worker ownership will be made available, which workers will be eligible, how ownership will be allocated, the timing of rights of ownership, and how ownership will be represented in the company. ${ }^{178}$ In answering these questions, boards of directors and management have the potential to offer ownership positions to significant stakeholders.

In the leveraged ESOF, a company's "contribution is defined by the annual debt obligation of the trust and the annual tax-deductible maximum of 25 percent of the pay of ESOP participants." 179 In an alternative form of ESOP, a non-leveraged ESOP, the annual contribution can be any amount "up to 15 percent of the participant's pay." 180 The non-leveraged ESOP allows a company to contribute stock to the ESOP or give it cash to purchase the stock. Similar to the leveraged ESOP, the stock is allocated to employees according to

176 Levin, supra note 173 , at 155.

177 See id. at 158 . Congress believed that eight benefits would result from the expansion of worker ownership of capital:

1) new wealth and productivity for the economy, 2) a chance for workers to accumulate a capital estate, 3) more jobs, 4) reduced fiscal strain, 5) a principled foreign policy, 6) union-management cooperation, 7) preservation of the marginal enterprise, and 8) expanded consumer purchasing power to "irrigate the economy."

Id. (footnote omitted).

178 See J. BLASI, supra note 164 , at 32.

179 Id. at 39.

180 Id. 
a specified formula. ${ }^{181}$ The corporation's contribution is a tax deductible business expense. ${ }^{182}$

In both the leveraged and non-leveraged plans, the government requires that every corporation develop a stock allocation formula that does not discriminate in favor of corporate officers, significant shareholders of the corporation's stock, or "highly-compensated" employees. ${ }^{183}$ In fact, however, most plans have allocated worker equity according to salary differences. ${ }^{184}$

Although assets may be allocated by formula to an employee's ESOP account, a vesting schedule controls when they actually belong to the employee. The vesting process creates incentives for employees to remain with the corporation. The process also governs the amount of time "a corporation can use the worker's equity in its business operations and when an employee actually controls ... her ownership."185 As in the allocation formula, the vesting process must not be discriminatory. Under typical plans currently in effect, employees begin to enjoy stock ownership vesting after five years of continuous employment with a corporation. ${ }^{186}$ The federal government will soon require that vesting be either 20 percent per year

181 A third type of plan, a tax-credit ESOP (sometimes termed a payroll-based stock ownership plan, "PAYSOP") allowed an employer who contributed securities (or cash to acquire securities) to a plan to qualify for credit against income tax liability equal to a prescribed percentage of the aggregate compensation of all employees under the plan. See Olson, supra note 170, at 773. These plans often excluded over 30 to 40 percent of the corporation's employees from participation. See J. BLASI, supra note 164 , at 116 . Benefits were required to vest immediately, meaning that there could be no forfeitures, even if the employee left the company. However, the workers' stock was required to stay in the trust for seven years. The plans were not allowed to borrow money and were required to pass voting rights through to participating employees. See Mutual GaIns, supra note 167, at 251. The Tax Reform Act of 1986 eliminated these tax-credit ESOPs. See J. BLASI, supra note 164 , at 116.

182 See J. BLASI, supra note 164 , at 116.

183 Under the Tax Reform Act of 1986,

[A]n employee is considered highly compensated if he or she has a salary in excess of $\$ 75,000$, owns 5 percent or more of the employer company, receives more than $\$ 50,000$ in annual compensation and belongs to the most highly paid group in the company (i.e., in the top 20 percent salary range), or is an officer in the employer company. Highly compensated employees must be identified in terms of the entire company not just a line of business or operating unit.

Id. at 47 (footnote omitted).

184 See id. at 48.

185 Id. at 51-52.

186 On the length of time before vesting, "[o]ne study indicates that 97 percent of ESOP companies begin vesting after five years of actual company service or less ... and complete it after ten years. Public companies tend to finish vesting earlier 
after three years of employment or 100 percent after five years. ${ }^{187}$ If an employee leaves before full vesting of his or her stock, any nonvested assets will be forfeited and divided among other employees or will be used to reduce corporate contributions to the ESOP. ${ }^{188}$

In almost all cases, employees are 100 percent vested by the time they retire. At that point, employees have total discretion to do whatever they desire with their shares. However, in some plans, the ESOP trustee has the right of first refusal on all shares an employee owns in the event that she wishes to sell them. ${ }^{189}$ Dividends are paid on stock held by an ESOT and are either allocated to employees' accounts or are passed through and paid directly to the participant in cash. $^{190}$

Voting rights in ESOP shares usually attach upon the allocation of stock. In publicly-held corporations, ${ }^{191}$ workers have the legal right to vote their allocation of shares held by ESOPs. ${ }^{192}$ Thus, employees are able to gain fuller ownership rights to their shares as they accumulate years of service and greater voting rights as they gain allocation. ${ }^{193}$ Alternatively, unallocated shares are usually voted by the ESOP trustee who is often chosen by management. ${ }^{194}$ The voting of unallocated shares may take several different forms.

(7.7 years) than private companies (10.4 years). Company size does not affect these patterns." Id. at 52.

187 This has been mandated in the Tax Reform Act of 1986 and will take effect in 1989-1991. In addition, the new tax law mandates that companies begin paying vested ESOP ownership benefits even if the employee leaves the firm for reasons other than death, retirement, or disability. See id.

188 See id. at 51.

189 See Mutual Gains, supra note 167, at 252.

190 See id.

191 "The law requires this of any company with a class of securities that must be registered under the Securities and Exchange Act of 1934 (that is, any corporation with assets of at least $\$ 1$ million and 500 or more stockholders)." J. BLAsI, supra note 164, at 55. A federal law, effective December 31, 1979, requires that ESOPs in privately-held firms pass-through voting rights to workers on major corporate issues that state laws or corporate charters mandate must be decided by more than a majority of the outstanding shares, including mergers, acquisitions, consolidations, or sales of all the corporation's assets. See id. The Tax Reform Act of 1986 changes the voting rights test for ESOPs of privately-held employers. Under the Act, the ESOP trustee is required to permit each participant to direct the vote of shares allocated to his or her account with respect to a specified list of corporate matters regardless of whether a majority vote is required by applicable corporate law. See I.R.C. $\$ 401$ (Supp. 1989).

192 See J. BLASI, supra note 164 , at 55.

193 See Mutual Gains, supra note 167, at 252.

194 "A recent study by the ESDP Association shows that a bank, trust company, or officers of the firm itself serve as ESOP trustees in 95 percent of the cases." J. BLASI, supra note 164 , at 55 . 
First, and in many cases, the corporation will provide that to the extent that voting decisions are not passed through to participants, they will be made by a committee composed of management. Second, a corporation may allow unallocated shares to be voted in proportion to the instructions given by the participants for voting allocated shares. Finally, ESOPs may contain provisions that require the trustee to be subject to the direction of a fiduciary who may appoint an investment manager. ${ }^{195}$ The investment manager will then have discretion to vote unallocated shares. In any case, the ESOP stock is voted on a one-share, one-vote basis. ${ }^{196}$

ESOPs provide a means by which the corporation may help employees "buy into" or hold a stake in its operations. If an ESOP is fully functioning and has been in effect for a number of years, a significant amount of stock may lie in employees' hands. ${ }^{197}$ If this is the case, these stakeholders may hold the means of compensation in the event of a takeover. If a hostile tender offer is launched for the corporation, the value of employees' vested ESOP stock will appreciate along with all other shares. Employees may also have a toehold in the decisionmaking processes of the board, since they may be able to vote a significant number of allocated shares. Their collective voting power may help to sound a voice either for or against the transaction and, if the corporation has a cumulative voting ${ }^{198}$ requirement for electing board directors, they may gain actual representation in the boardroom.

Although the above description of ESOPs has been a rough survey at best, it is evident that they may play a significant role in providing employees with protection against risks associated with hostile takeovers. If a plan can be created under governmental regulations well in advance of any takeover events, it would seem apparent that directors and management had considered the interests of employees and established a mechanism for compensation in the event of a change of control. Since ESOPs enjoy a favorable tax treatment,

195 See id.

196 See id.

197 See Rosen \& Quarrey, How Well Is Employee Ownership Working?, 65 HaRv. Bus. REv. 126, 128 (1987).

198 Cumulative voting "is designed to allow shareholder groups to elect directors in rough proportion to the shares held by each group and thus to guarantee minority representation on the board. ... [E]ach share ... carries a number of votes equal to the number of directors to be elected, but a shareholder may 'cumulate' his votes." L. Solomon, D. Schwartz \& J. Bauman, supra note 2, at 299. "Seventeen states currently mandate cumulative voting, and about thirty states permit it." $I d$. at 1364. 
their adoption should face little if any resistance among employees and shareholders. ${ }^{199}$

In order for an ESOP plan to represent a successful application of nonshareholder constituency statutes, however, it must not function as a substitute for existing wages and benefits. ${ }^{200}$ The ESOP must function as a method of transferring ownership to employees in exchange for governmental tax advantages ${ }^{201}$ and as a tool for raising motivation and productivity ${ }^{202}$ in the workplace. If the ESOP has been adopted at the price of reduced compensation or the elimination of a pension plan, it will simply represent a re-mixing of employees' compensation and not an added security or protection plan. As a result of the availability of tax advantages to corporations and lenders to leveraged plans, explicit ESOPs may be established which assist employees in becorning stock owners, provide them with added compensation, and allow them to share in the premiums from takeovers realized only by shareholders. ${ }^{203}$

This system of explicit contracting differs from the successorship clause and silver parachute agreements since it involves ownership and the potential for control. However, if a hostile takeover is

199 But see J. BLASI, supra note 164, at 45 (stating that "[s]ome observers have suggested that trade unions want to rely on contracts to control all forms of compensation benefitting their nembers and hence are suspicious of employeeownership plans that tie a worker's capital accumulation to decisions by management and/or the performance of the firm").

200 Some corporate ESOP's have been adopted either as alternative compensation plans or in exchange for wage and benefit concessions by workers. For example, Polaroid Corporation required that workers exchange a combination of wage cuts, profit-sharing reductions, and pay scale decreases, totalling $\mathbf{3 6}$ million dollars, for the implementation of an ESOP plan. See Shamrock Holdings, Inc. v. Polaroid Corp., 559 A.2d 257, 27 I (Del. Ch. 1989); I.M. (Mac) Booth of Polaroid-The ESOP Solution, INST. INVESTOR, Sept. 1989, at 87-88 (interviewing Polaroid's CEO on its ESOP). In 1982, "Pan Am enployees gave up 10 percent of their wages for a nonleveraged ESOP and one seat on the board of directors." MUTUAL GaINS, supra note 167, at 254; see also Olson, supra note 170, at 775-80 (describing the Pan Am and Chrysler Corp. ESOP arrangements).

201 In 1983, for example, the National Center for Employee Ownership determined that 40 percent of all ESOPs had been established primarily for tax purposes. See Mutual Gains, supra note 167, at 254. Taxpayers may be paying for benefits received by these plans. See id. In addition, stockholders may also pay for the establishment of these plans as a result of dilution if new shares are issued to the ESOP. See id.

202 See Rosen \& Quarrey, supra note 197, at 127-28 (comparing the performance of ESOP companies with other similar companies and concluding that " $t]$ he data couldn't be clearer: companies do better . . . after setting up ESOPs" as a result of increased worker participation and motivation); see also Polaroid, $559 \mathrm{~A} .2 \mathrm{~d}$ at 274 ("[T]he evidence is uncontradicted that ESOPs promote productivity.").

203 See Mutual Gains, supra note 167, at 253-54. 
successful, employees' ability to realize the appreciation of their vested ESOP stock upon termination could be a surrogate for any compensation that might have been provided through parachute plans. It may be the case, though, that a combination of an ESOP, parachute plan, or successorship clause will best protect the interests of, or reduce the added risks experienced by, workers in a hostile takeover. ${ }^{204}$

\section{Problems of Managerialism}

A critique of the proposed use of explicit contracts by directors and officers might begin by claiming that it will foster managerial entrenchment. The argument would follow that the use of explicit contracts in the name of supporting nonshareholder constituency statutes might further the goals of incumbent managements of corporations which are potential takeover targets. Furthermore, if managers are able to encumber the corporation with enough unwieldy contracts, the corporation might become unattractive to potential bidders and thus harm shareholders' interests, while allowing executives to retain their jobs. Ultimately, the explicit contracting process might be seen as a method of providing management with a multifaceted, super-corporate defense. ${ }^{205}$

This critique, however, side-steps an important condition of the proposed explicit contracts: all of these contracts have been used by corporations in non-takeover settings. For example, ESOPs have been widely used by corporations for many years. ${ }^{206}$ Legislative and judicial standards have been put into place which limit directors' and officers' abilities to abuse these forms of contracts. ${ }^{207}$ In the ESOP context, tax reform laws have set specific guidelines for the level of benefits and compensation available under the plans. ${ }^{208}$ Tax laws have also been used to place a reasonable limit on the amount of compensation paid out under parachute agreements. ${ }^{209}$

In addition to the fact that the proposed contracts are often adopted in the ordinary course of business, another significant con-

204 But see Coffee, supra note 7, at 76 (concluding that ESOPs may cause employees to become "overinvested" in their corporation and thereby increase their risk by becoming nondiversified residual risk bearers).

205 See supra note 41.

206 See Olson, supra note 170, at 742-80 (presenting case studies of ESOPs over the years).

207 See supra notes $149 \& 183$ and accompanying text.

208 See supra notes 167, 172, 181, 183 \& 191 and accompanying text.

209 See supra note 149. 
dition relates to their ex ante adoption. It is not proposed that these explicit contracts be adopted in the heat of a takeover battle, but rather, that they be adopted well in advance of any major market activity. Courts have indeed been reluctant to uphold ESOPs that have been adopted solely as a response to a hostile tender offer, thus solidifying control of the company in management's hands, instead of for the benefit of employees. ${ }^{210}$ The sale of stock to an ESOP during a takeover battle will be closely scrutinized by the court to determine whether the board's actions were in good faith and were reasonably related to the threat posed to shareholder interests by the hostile bid. ${ }^{211}$

210 As an example, in the early 1980s, Norlin Corporation was the subject of a takeover bid; it commenced defensive action by issuing new voting stock to a whollyowned subsidiary and to a newly-established ESOP. The board of directors held control of the voting rights of the newly issued shares and thereby diluted the voting power of the bidders. The Second Circuit sustained an injunction against the stock issuances. On the terms of the ESOP, the court held that in the context of takeovers, an analysis of the directors' actions begins with the business judgment rule; however, "[o]nce self-dealing or bad faith is demonstrated, the duty of loyalty supersedes the duty of care, and the burden shifts to the directors to "prove that the transaction was fair and reasonable to the corporation.' " Norlin Corp. v. Rooney, Pace Inc., 744 F.2d 255, 264-65 (2d Cir. 1984) (citation omitted). The court found that the evidence supported a finding of self-dealing by the board of directors; the timing of the stock issuance to the ESOP inclicated that it was for the purpose of solidifying control of the corporation and not for the employees' benefit. The court held that "the ESOP was created solely as a tool of management self-perpetuation." Id. at 266 (footnote omitted).

211 See, e.g., Norlin Corp. v. Rooney, Pace Inc., 744 F.2d 255 (2d Cir. 1984); Buckhorn, Inc. v. Ropak Corp., 656 F. Supp. 209 (S.D. Ohio), aff'd by sum. ord., 815 F.2d 76 (6th Cir. 1987); British Printing \& Communications Corp. v. Harcourt Brace Jovanovich, Inc., 664 F. Supp. 1519 (S.D.N.Y. 1987); AC Acquisitions Corp. v. Anderson, Clayton \& Co., 519 A.2d 103 (Del. Ch. 1986); Frantz Mfg. Co. v. EAC Indus., Inc., 501 A.2d 401 (Del. 1.985). The court in Buckhorm provided a clear summary on the issue of scrutiny:

[W]hile it is certainly permissible for the directors to adopt measures for the benefit of its employees during the midst of a corporate control struggle, the directors must show that "there are rationally related benefits accruing to the stockholders" from adopting such measures. Furthermore, the Court believes that it is appropriate to look at such factors as "the timing of the ISSOP's establishment, the financial impact upon the company, the identity of the trustees and the voting control of the ESOP shares" in determining whether the ESOP was created to benefit the employees and not simply to further entrench management.

Buckhorn, 656 F. Supp. at 231-32 (footnotes omitted); $c$. British Printing \& Communications Corp. v. Harcourt Brace Jovanovich, Inc., 664 F. Supp. 1519 (S.D.N.Y. 1987). Harcourt Brace Jovanovich proposed to issue new stock to an existing ESOP as part of a defensive recapitalization. The district court upheld Harcourt Brace's claim that its contribution to the ESOP was necessary to provide employees with an incentive for increased productivity to assist in the recapitalization. The court found that a 
If directors' actions in adopting an ESOP during an attempted takeover were found not to be reasonably related to the threat posed or disinterested, the court might next examine the overall fairness of the ESOP to the corporation and its shareholders. Using this type of examination, the Delaware Chancery court upheld the validity of an ESOP adopted by Polaroid Corporation in the face of a hostile acquisition bid by Shamrock Holdings. ${ }^{212}$ The court concluded that the corporation's directors were found to have been inadequately informed during a special board meeting in which the ESOP was considered and the directors failed to "take any investigation as to the nature of the purported threat and ... failed to evaluate whether the ESOP constituted a reasonable response to the "threat." 213 Therefore, the court did not apply the business judgment rule and instead scrutinized the adoption of the ESOP under a test of total fairness. ${ }^{214}$ Although the ESOP was found to have some dilutive effect on the holdings of other stockholders, the court found it to be "fundamentally fair."215 The ESOP's fairness rested upon the court's conclusion that the plan was indeed "shareholder neu-

pass-through voting provision for the shares held by the ESOP, in which shares allocated to participants would be voted by them and unallocated shares would be voted proportionately with the directed votes of the unallocated shares, sufficiently avoided any problems of managerial entrenchment. See id. at 1531.

212 See Shamrock Holdings, Inc. v. Polaroid Corp., 559 A.2d 257 (Del. Ch. 1989). Polaroid's board of directors initially considered adopting a comprehensive ESOP in 1985 and subsequently adopted such a plan in early 1988 . By mid-1988, Shamrock Holdings began to acquire Polaroid's common stock in order to facilitate an acquisition. At this point, Polaroid's directors began to consider expanding or broadening the company's ESOP. See id. at 265 . In response to acquisition overtures by Shamrock, Polaroid directors held a special meeting in which they considered a "comprehensive plan" of defense against the "hostile" bid by Shamrock. This plan consisted of four elements, including: the reorganization of Polaroid's businesses; the use of voluntary and early retirement plans to reduce the work force; the ESOP; and a decision to begin production of 35 millimeter film. The directors unanimously approved the implementation of a broadened, 300 million dollar ESOP. The amended plan called for a number of employee wage and benefit concessions in order to help assure "shareholder neutrality"-whereby shareholders would not directly pay for the ESOP. See id. at 271-72; supra note 200 and accompanying text. Soon thereafter, Polaroid refused to meet with representatives from Shamrock. Shamrock instituted injunctive action, claiming that "Polaroid's directors breached their fiduciary duties in adopting [the ESOP] and . . . breached certain promises to Shamrock in connection with a meeting scheduled [to take place the day after Polaroid's special board meeting]." Polaroid, 559 A.2d at 259.

213 Id. at 270.

214 See id. at 271.

215 See id. at 275. 
tral,"216 "structurally fair in its voting and tendering provisions,",217 and not an unreasonable anti-takeover measure. ${ }^{218}$

The Polaroid opinion places the concept of "shareholder neutrality" as an important element in determining the overall fairness and validity of an ESOP adopted in a takeover setting. It may be quite difficult, however, to unify this concept with the goals of nonshareholder constituency statutes. In order to provide labor with significant contractual protection against takeovers, it may not be helpful for a corporation to create an ESOP based on significant wage concessions or benefit reductions. Thus, under nonshareholder constituency statutes, corporations should attempt to balance the long-term tax advantages of ESOPs and the building of employee motivation and productivity with shareholders' interests in avoiding dilution of their investments. This may be accomplished if the ESOP plan is adopted before the company becomes the subject of a takeover attempt and if the plan has been in effect for a number of years. 219

Courts may also be reluctant to uphold golden parachute agreements that were adopted in the heat of a hostile takeover attempt. ${ }^{220}$ Similar to the ESOP case, boards of directors should consider adopting silver or tin parachutes well in advance of any takeover activity. ${ }^{221}$ This would allow the boards to consider fully the issues surrounding such contracts, including reasonable levels of compensation. The directors' consideration of compensation afforded by an agreement should be guided by tax law limits and the corporate waste doctrine. ${ }^{222}$ The contracts are more likely to be enforced if they have been approved by a disinterested majority of the board of directors or a board committee, further limiting incentives for mana-

216 The court concluded that "shareholder neutrality" would be achieved by the fact that although the issuance of ESOP shares might dilute shareholders' investments, the ESOP required substantial wage concessions (give-ups) by workers totalling 36 million dollars, and the plan would promote productivity in the workplace and therefore increase corporate earnings. The net effect on the value of existing shareholders' investments in the corporation would most likely be "neutral." See id.

217 Id.

218 See id. at 274.

219 This would allow the corporation to benefit from the cumulative effects of tax incentives and increased worker productivity and to avoid the need to extract wage concessions from employees. See Rosen \& Quarrey, supra note 197, at 127.

220 See 2 ShaRK RePELLANTS, supra note 61, at 436.7-436.8; supra note 149 and accompanying text.

221 See 2 Shark Repellants, supra note 61, at 436.8 .

222 See supra note 149 and accompanying text. 
gerial entrenchment. ${ }^{223}$ Finally, depending upon the relative size of the corporation or scope of the silver or tin parachute, the agreement may only have a minor effect upon the purchase price of the company. If the acquiring company chooses to retain most of the workers covered by such an agreement, it may result in little, if any, costs or payments. ${ }^{224}$

Successorship clauses, silver or tin parachutes, and ESOPs will not become additional corporate defenses if they are used reasonably and in advance of any takeover activity. It is important that directors and officers seriously consider and act upon employees' interests ex ante to major corporate decisions. If this is achieved, explicit contracts will be put into place which will subsequently accommodate these interests during a change of control or major corporate decision.

\section{Conclusron}

This Comment proposes a basic solution to interpreting the responsibilities of corporate directors and officers to employees under state nonshareholder constituency statutes. By negotiating over or providing labor with contractual risk protection ex ante to a takeover, directors establish that they have considered the stakeholders and their concerns. These contracts may take the form of agreements which either attempt to secure employment of unionized employees after the takeover (or else provide the workers with damages), to pay a lump-sum severance amount to employees upon termination, or to compensate employees with equity which may be cashed out with a takeover. Each agreement is a form of premium sharing, impacting upon the future purchase price of the corporation. Thus, in a takeover, shareholders will only realize a gain net of the value of the contractual arrangements with employees.

Although all of these arrangements are currently in use in major corporations, it may be incumbent upon directors and officers to examine their relative compensatory impact on workers upon a change of control. If, for example, it is determined that a corporation's current ESOP is too new to have a relative impact upon employees' level of ownership of stock, directors may need to use other explicit contracts in order to compensate or protect workers.

Employees represent a significant group to be accounted for

223 See 2 SHARK REPELLANTS, supra note 61, at 436.7; supra text accompanying note 157 .

224 See 2 ShaRk Repellants, supra note 61, at 436.7-436.8. 
under nonshareholder constituency statutes; however, there are other interested stakeholders as well. ${ }^{225}$ In the context of employees, there are a number of explicit contracts that already exist which might protect their interests after a change of control. This may not be the case for other constituencies, especially those who do not have any contractual relationship with corporations, such as local rommunities. For example, if workers are laid off and plants are closed in the "aftermath of either a takeover or a defensive tactic that increases corporate leverage, much of the resulting costs will fall on the state, which typically will be required to pay increased welfare benefits and make other transfer payments."226 Furthermore, local communities often create firm-specific investments, such as schools and social services, that may be lost or diminished without a major plant or corporate headquarters. ${ }^{227}$

It may be possible, however, for states and local communities to contract explicitly with corporations in order to protect their firmspecific capital. The community could offer to provide social services related to the corporation or its employees in return for explicit guarantees. ${ }^{228}$ These guarantees might take the form of severance or relocation cost agreements that the target corporation would include in any takeover agreement. ${ }^{229}$

Implicit in the foregoing proposals is the fundamental assumption that corporate governance is circumscribed by the states. The Supreme Court has continuously emphasized that the states have the

225 See supra notes $11 \& 111$ and accompanying text.

226 Coffee, supra note 7 , at 72.

227 See Singer, supra note 13 , at 718 .

228 See, e.g., Jones, Plant Closings: The Business View, 26 DuQ. L. Rev. 419, 421-22 (1988) (examining services that might be provided in the event of a plant closing or shut-down).

229 According to Professor Coffee, local communities tend to be "' 'novices' matched against a 'repeat player' ['corporation] who sees that it is in a 'buyers market' full of communities eager to attract such employers. This trend is increasing as small towns now bid for major industrial plants by offering to install special improvements and to develop a surrounding infrastructure of schools and other social services." Coffee, supra note 7, at 72 n.199; see also Ansberry \& Sasaki, Ohio Town Gives Look at Future for Site of GM's New Saturn Plant, Wall St. J., Aug. 30, 1985, at 17, col. 4. (discussing the impact a Honda plant had on a small community and what types of arrangements were guaranteed in order to attract the company). Despite these concerns, nonshareholder constituency statutes provide a forum for beginning negotiations over community contracts with the corporation. If corporate directors can demonstrate that they have negotiated and approved community-oriented contracts that will survive a takeover or restructuring, they may legitimately focus on shareholder (and other stakeholders') interests when making decisions. 
authority to define their own rules for corporate governance. ${ }^{230}$ Thus, the states have discretion to define the relationships of stakeholders to the corporation; for example, a state could legitimately assign employees (or all stakeholders) voting rights. ${ }^{231}$ Although nonshareholder constituency statutes do not quite change the balance of power between shareholders and stakeholders, they open the blinds on the windows of the boardroom and allow directors to see and consider the interests of affected groups surrounding the corporation.

If the directors are in the midst of a hostile takeover, however, the windows may be steamed up as a result of the mounting tension. If stakeholder interests have already been accounted for (on clearer days) through settled contracts, the directors may more comfortably focus on the shareholders' desires.

230 See Santa Fe Indus., Inc. v. Green, 430 U.S. 462, 478-79 (1977). See generally CTS Corp. v. Dynamics Corp. of America, 481 U.S. 69, 92 (1987) (noting that "[t]he Constitution does not require the States to subscribe to any particular economic theory").

231 See Coffee, supra note 18 , at 461 . 
